\title{
Novel No-wash Luminogenic Probes for the Detection of Transporter Uptake Activity
}

Dana Mustafa, ${ }^{\mathrm{a}}$ Dongping Ma, ${ }^{\mathrm{b}}$ Wenhui Zhou, ${ }^{\mathrm{a}, *}$ Poncho Meisenheimer, ${ }^{\mathrm{a}}$ James J. Cali ${ }^{\mathrm{b}}$

${ }^{a}$ Promega Biosciences LLC, 277 Granada Drive, San Luis Obispo, CA 93401; ${ }^{b}$ Promega

Corporation, 2800 Woods Hollow Road, Madison, WI 53711-5399

\section{Supporting Information}




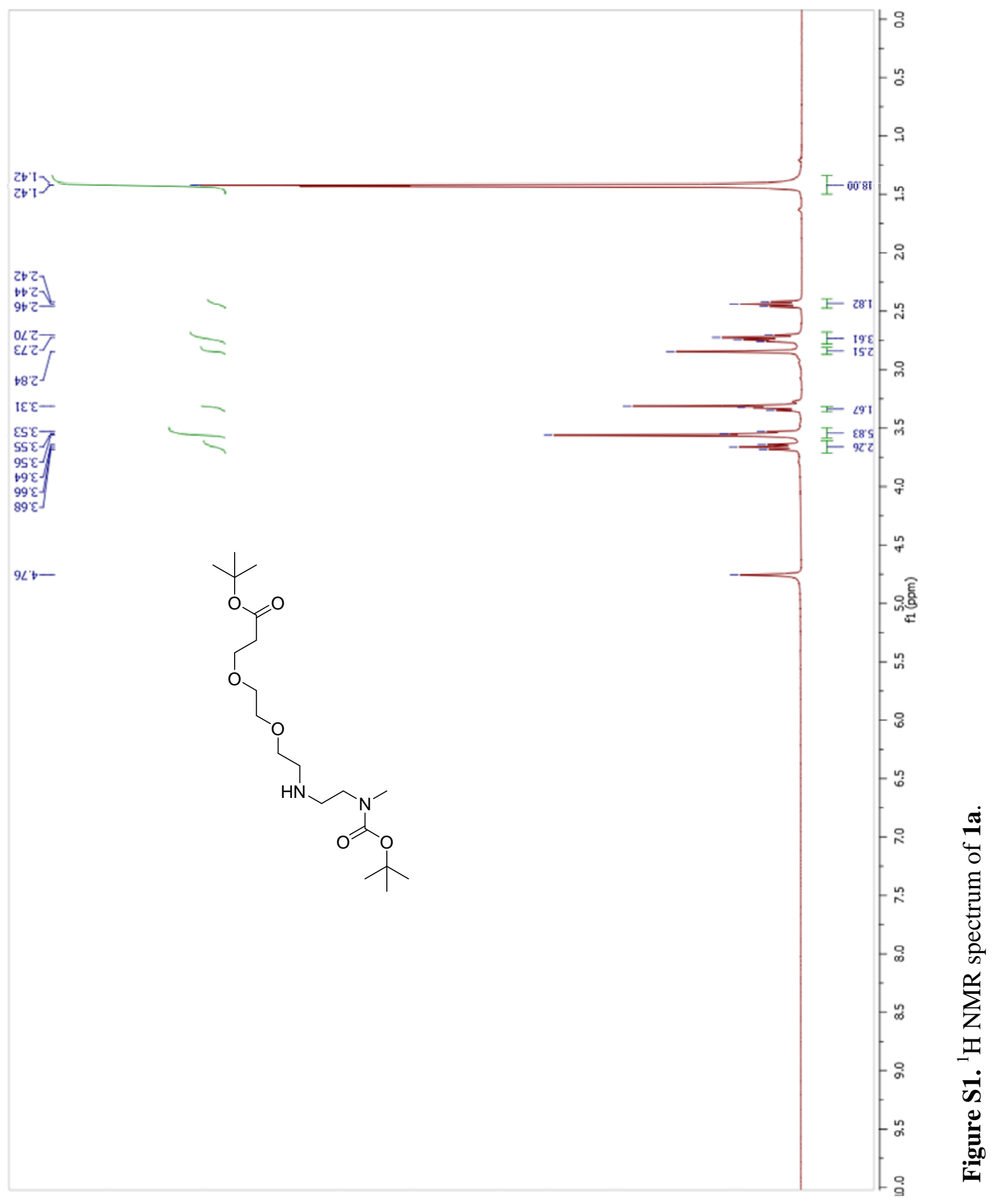




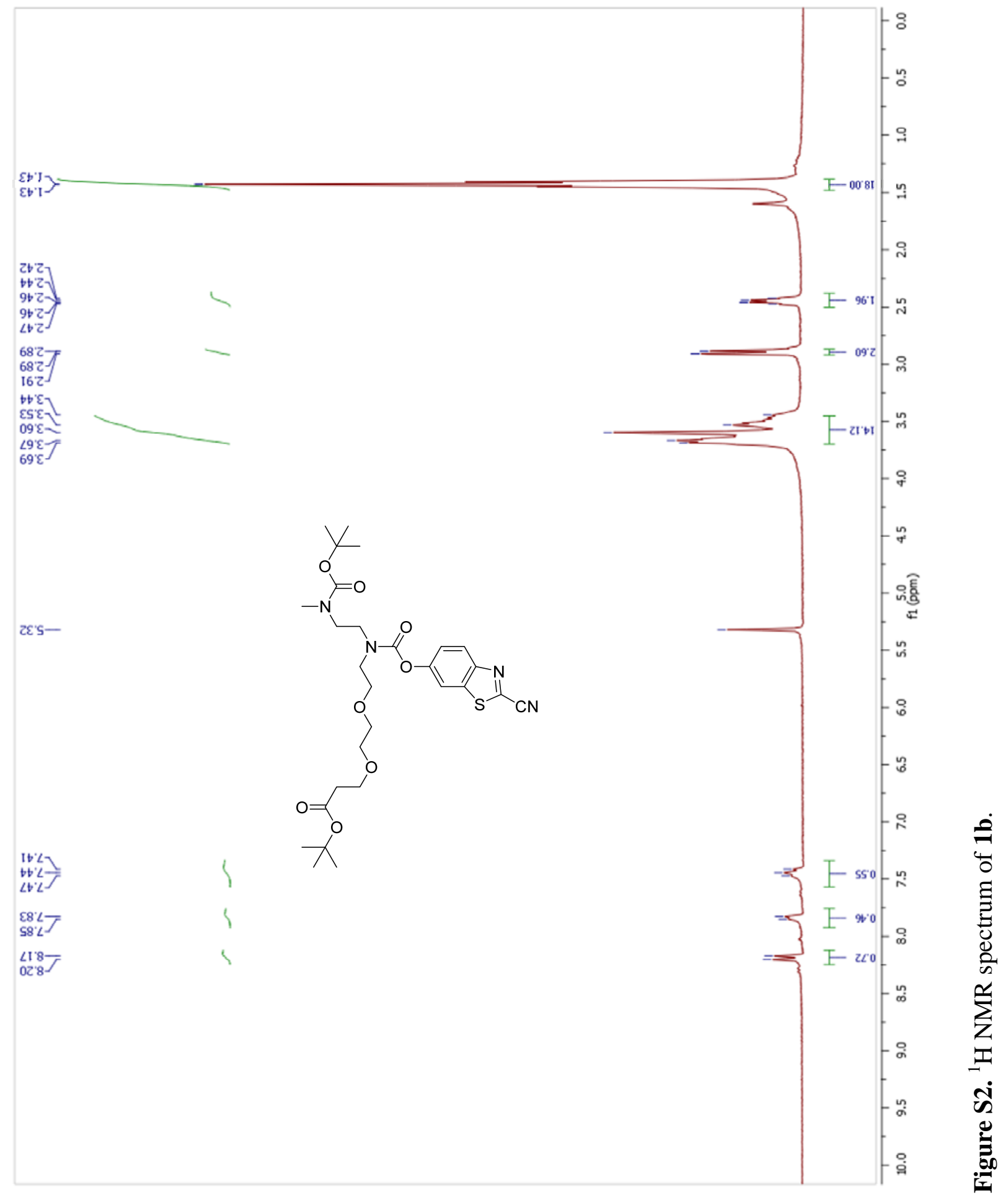




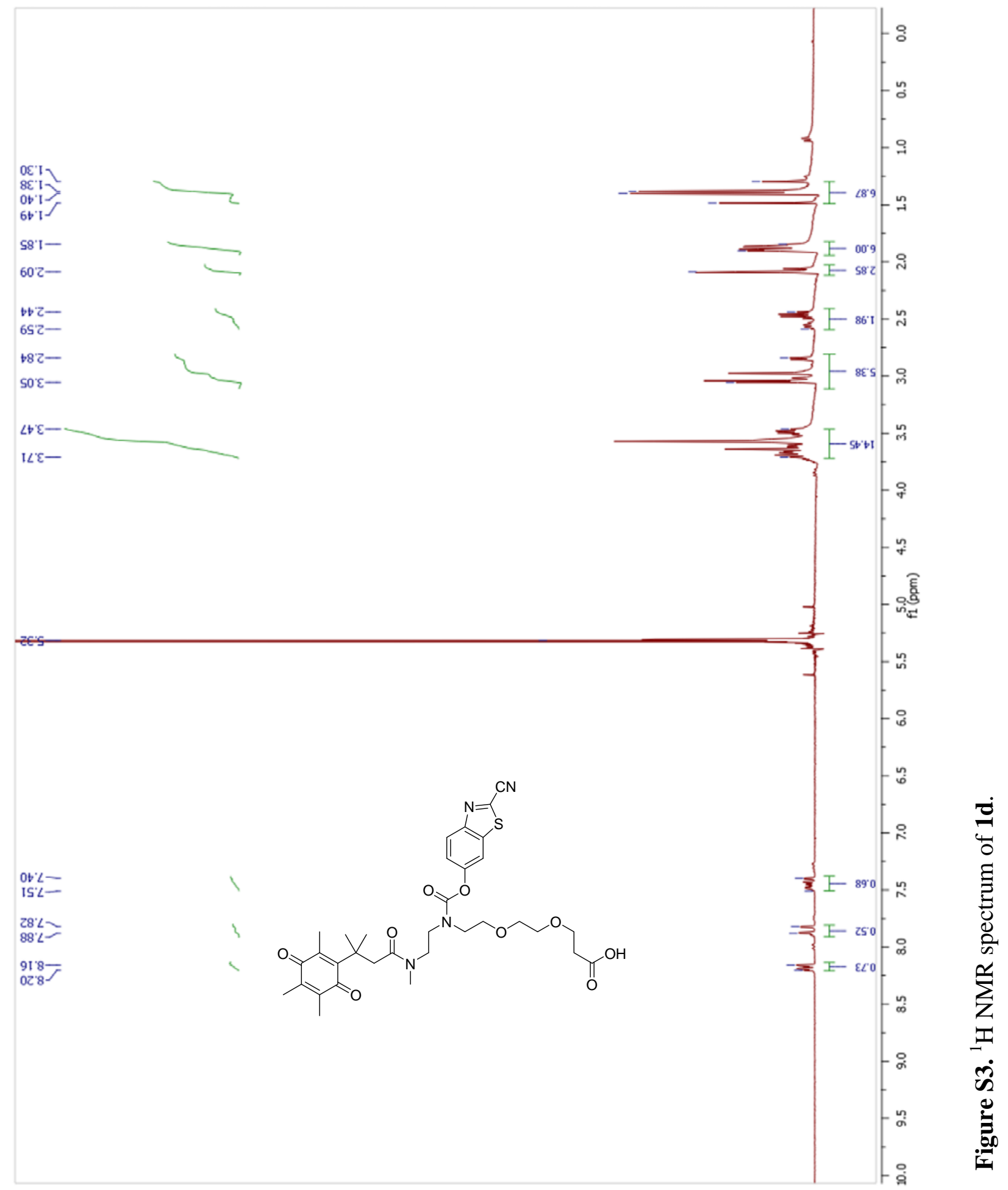




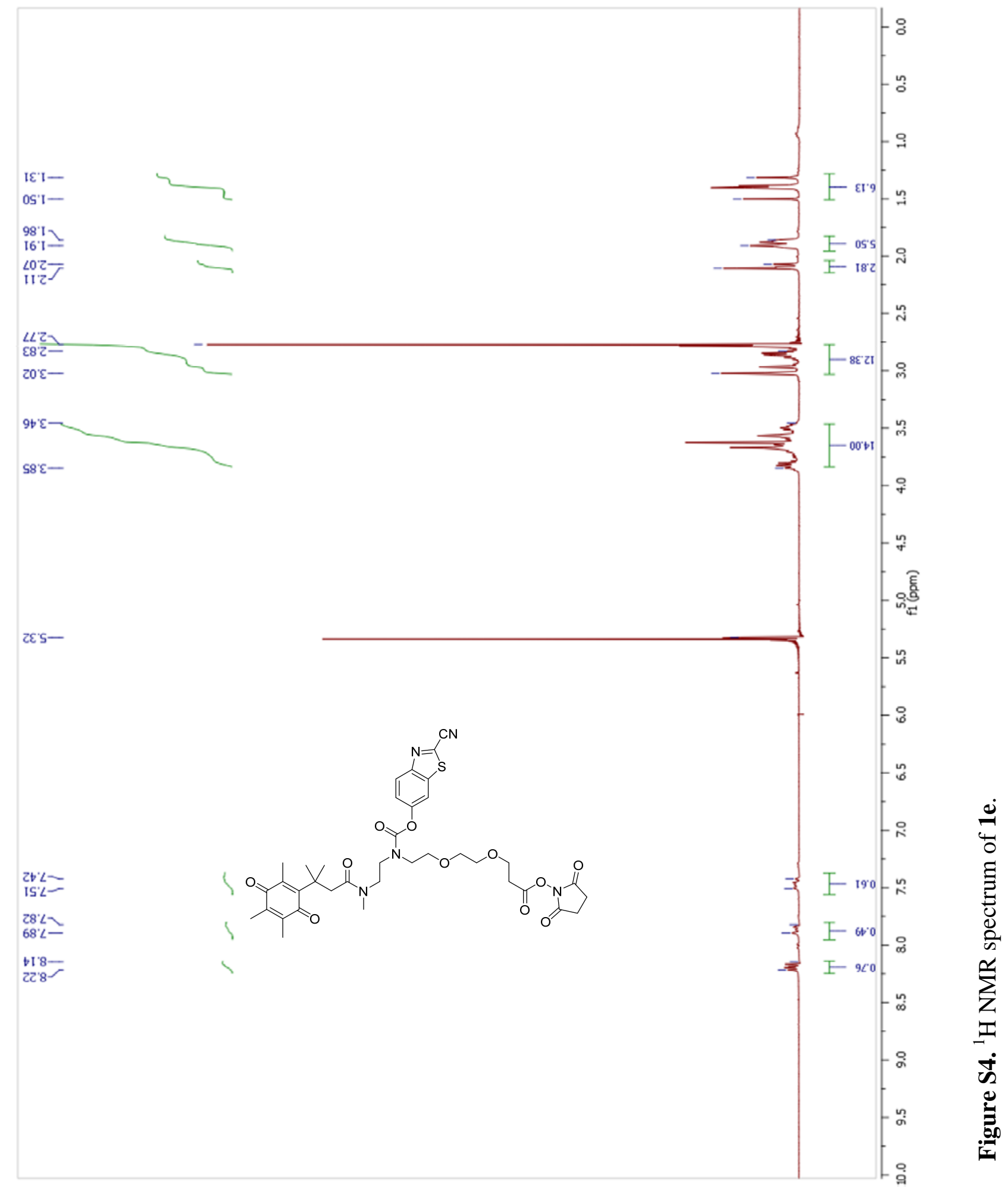




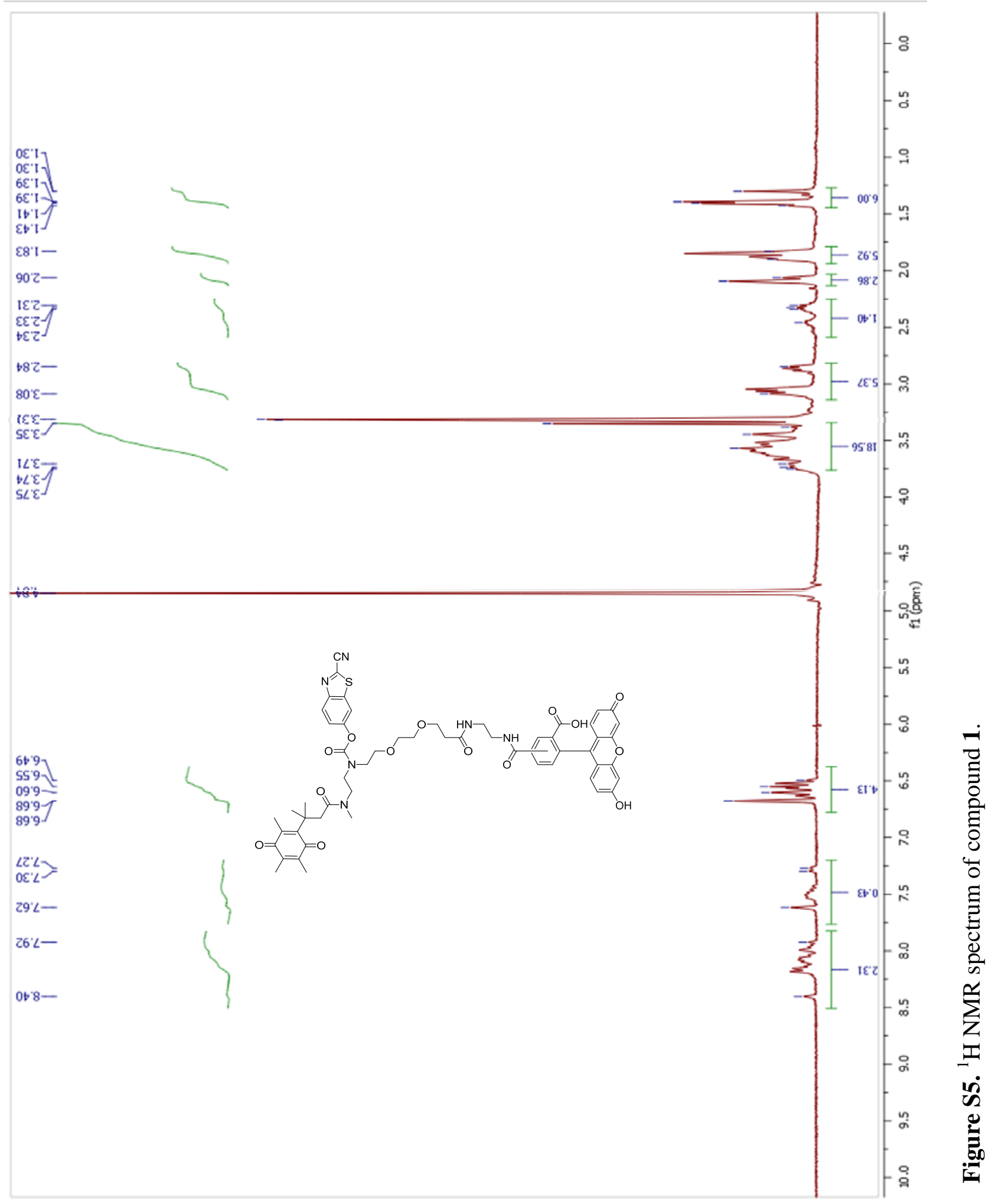




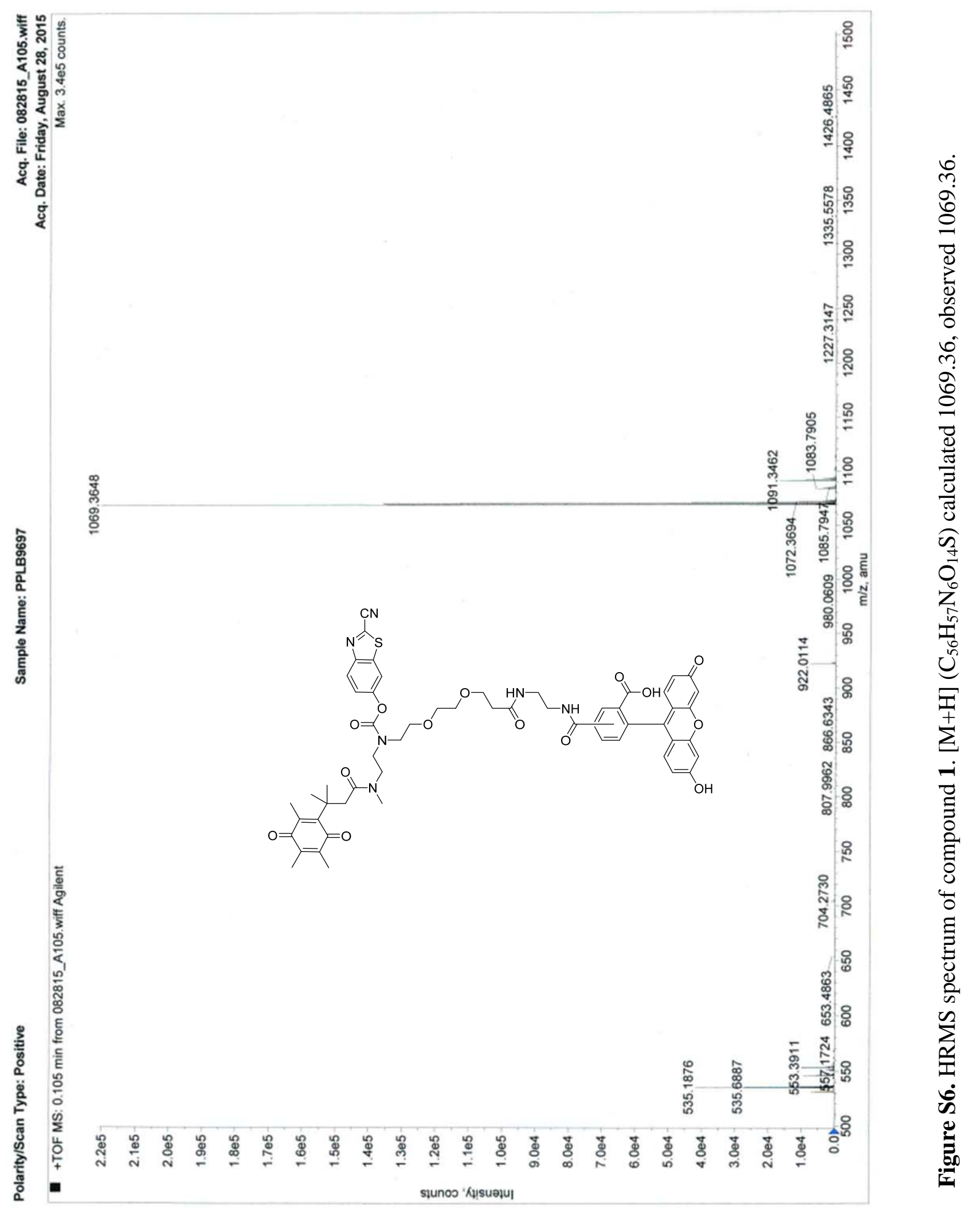




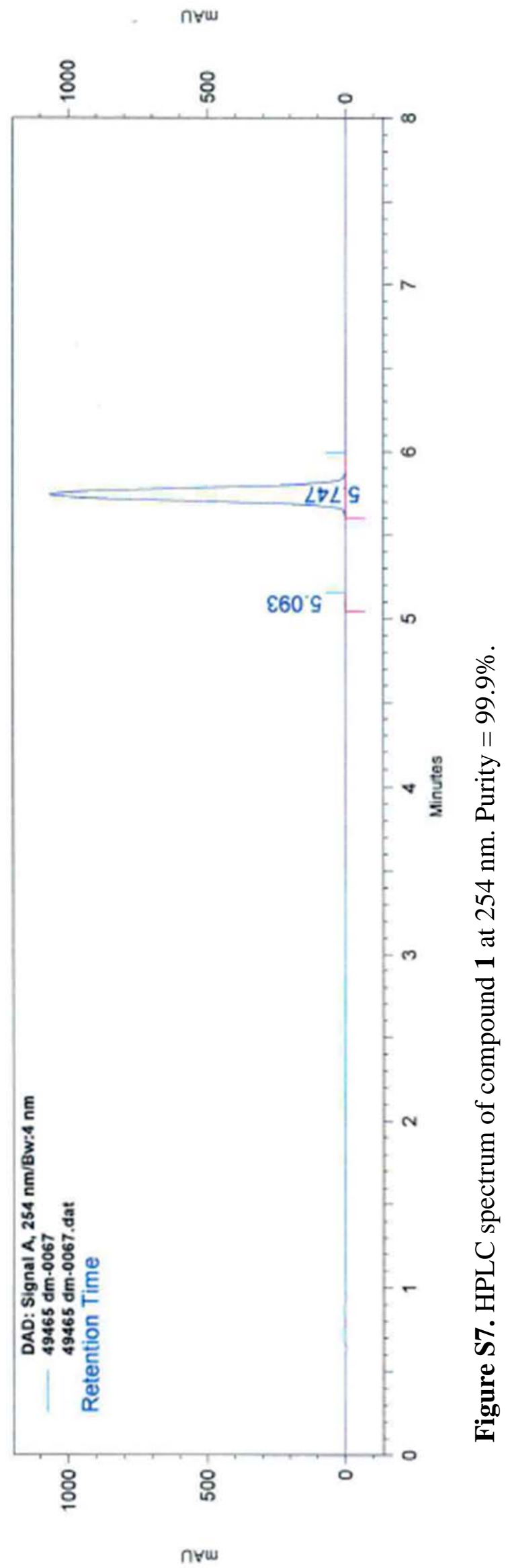




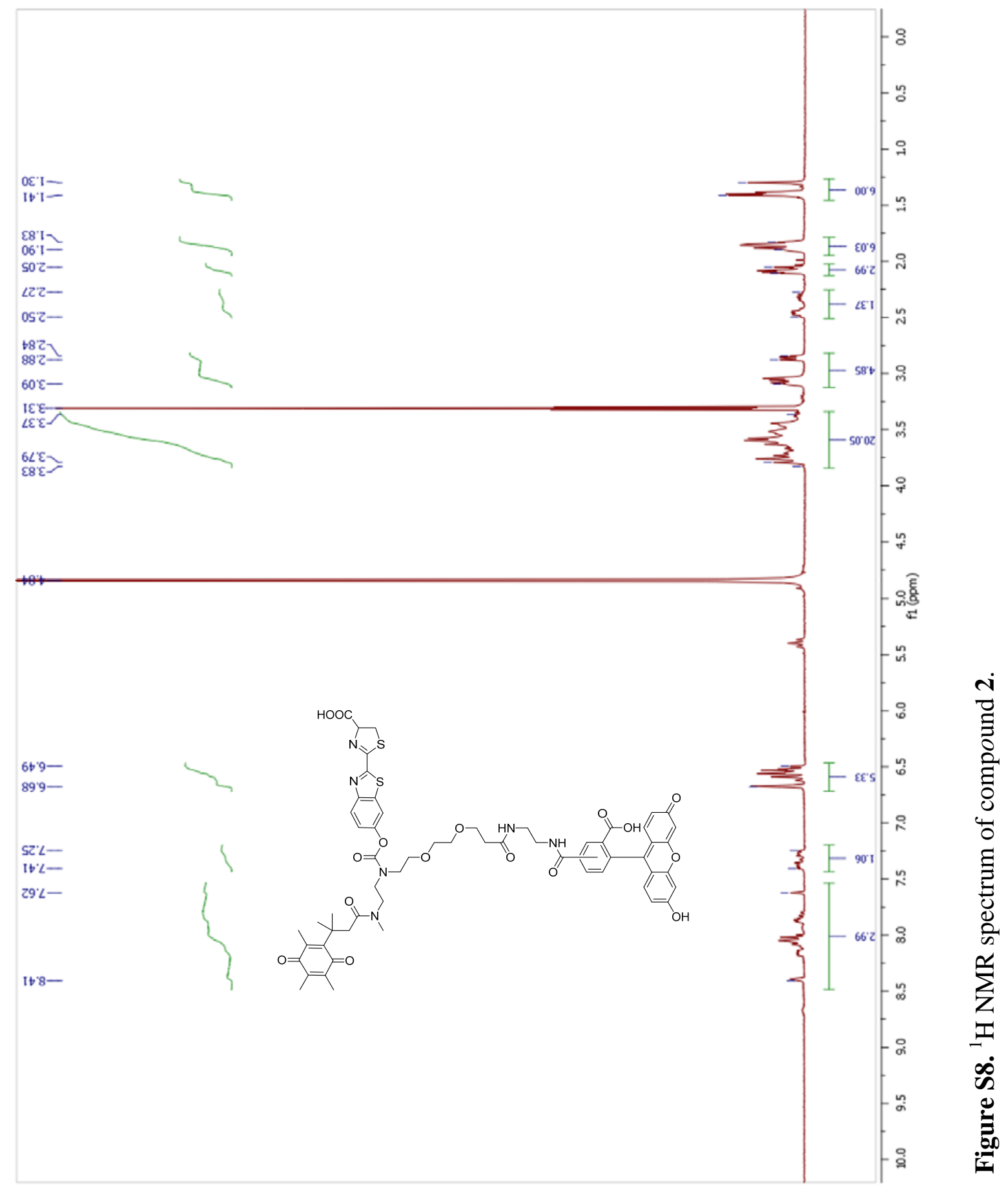




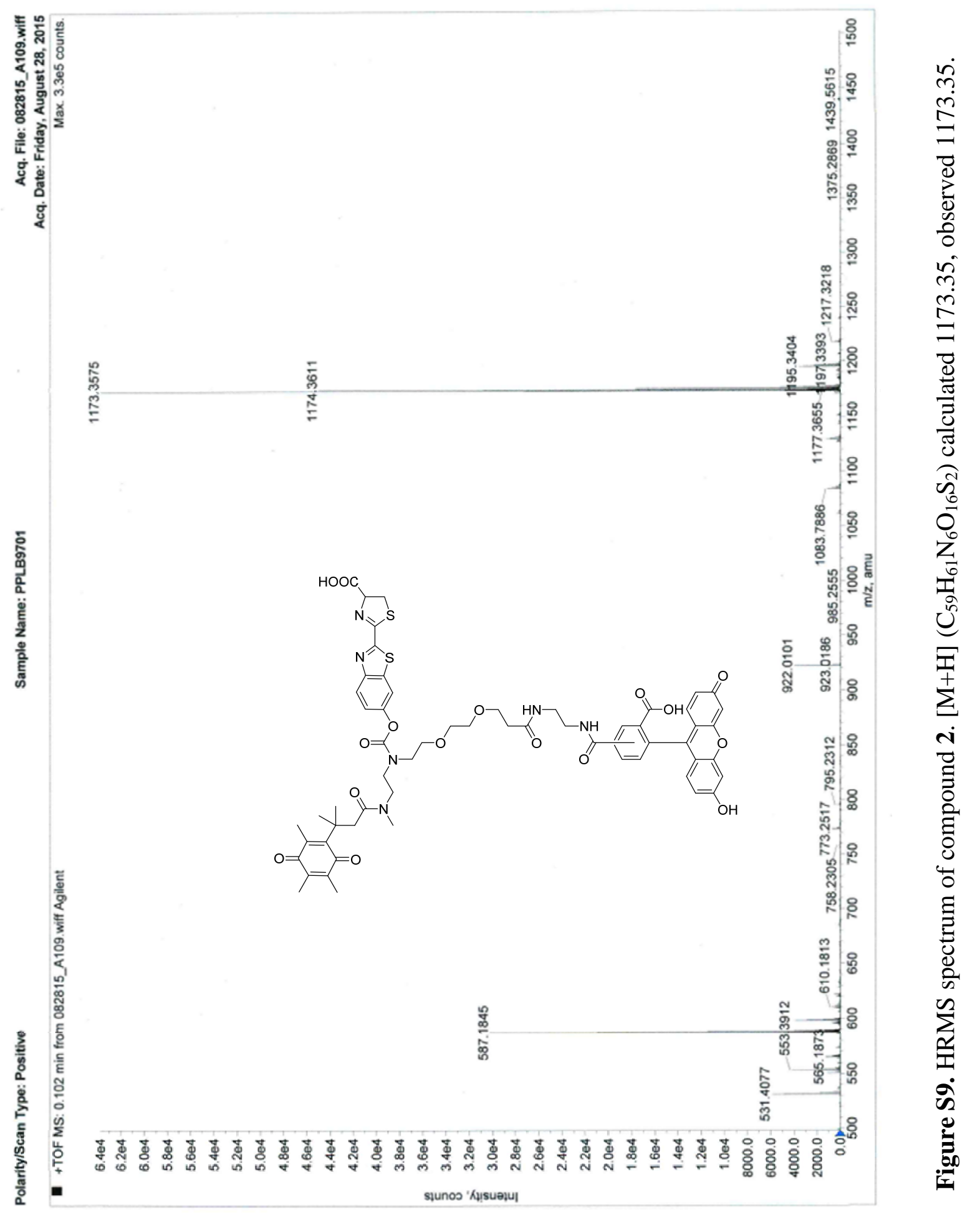




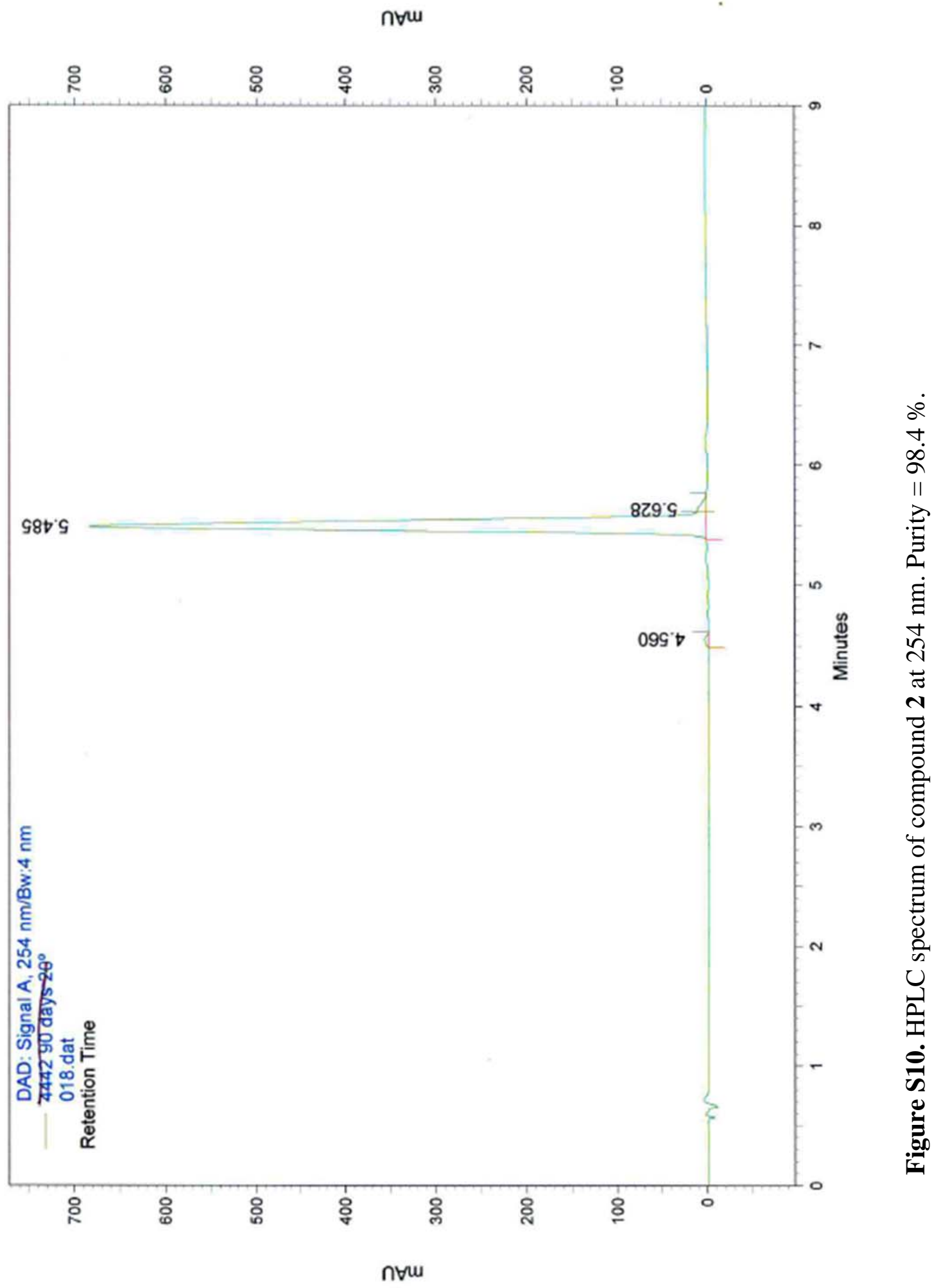




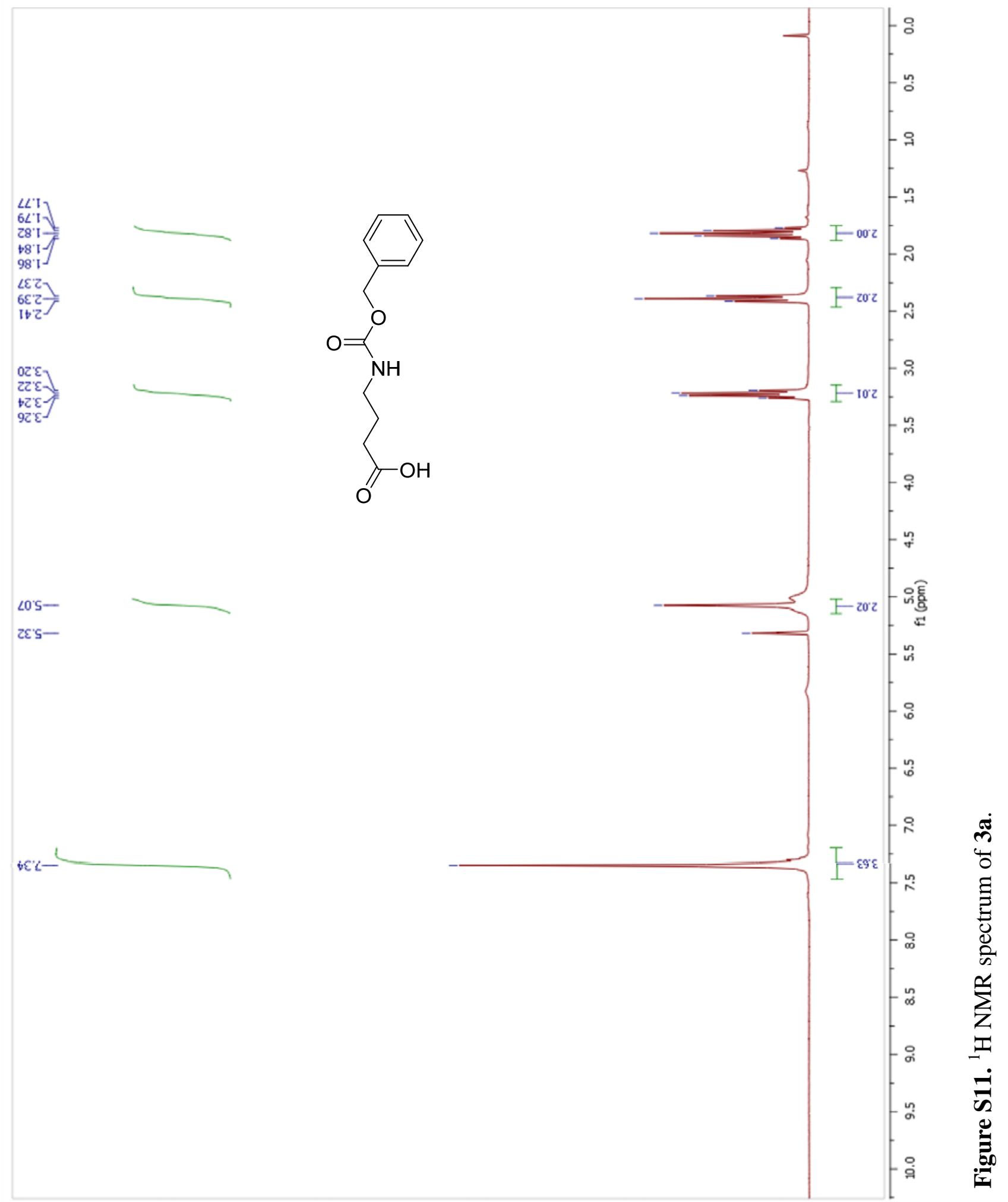




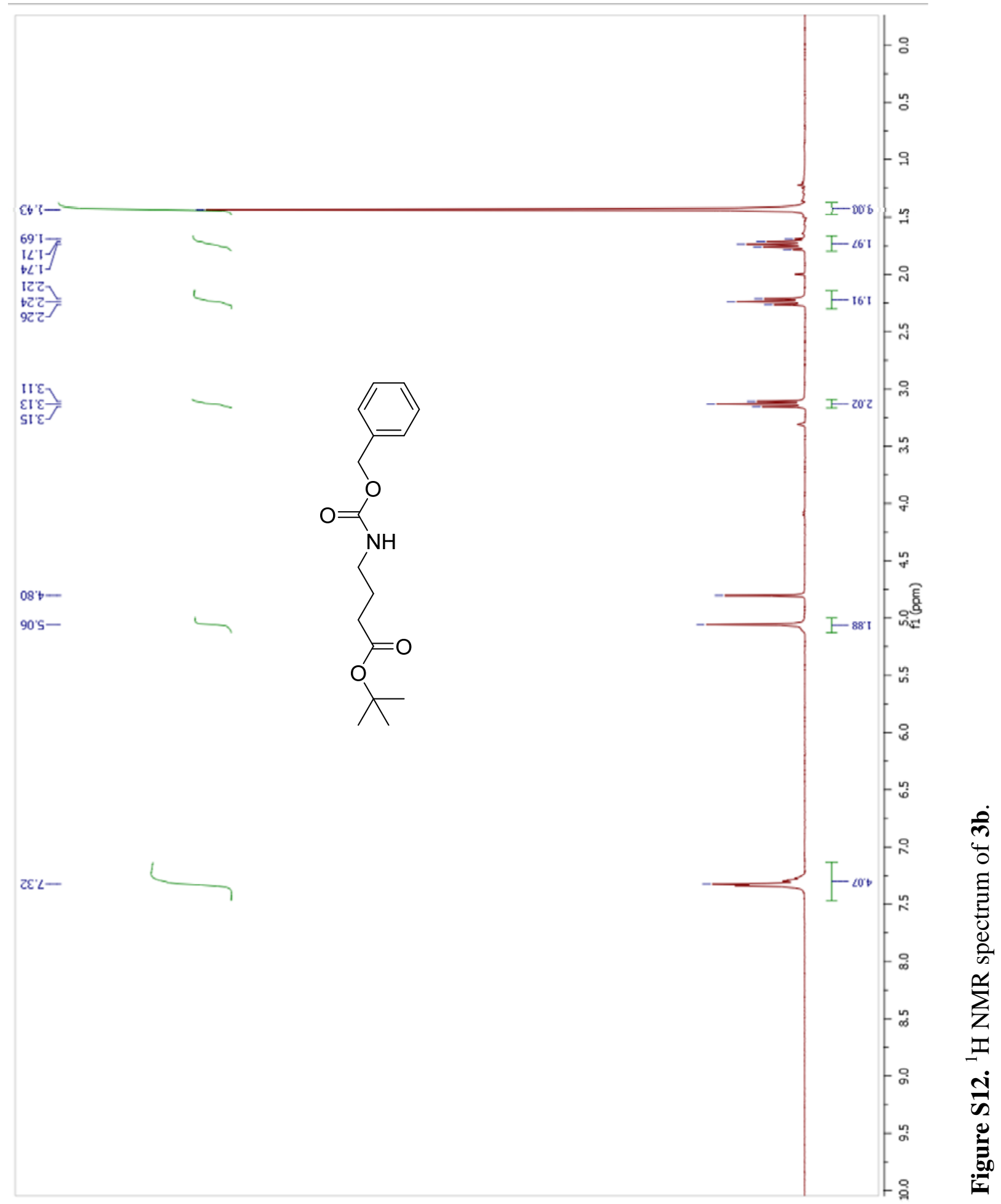




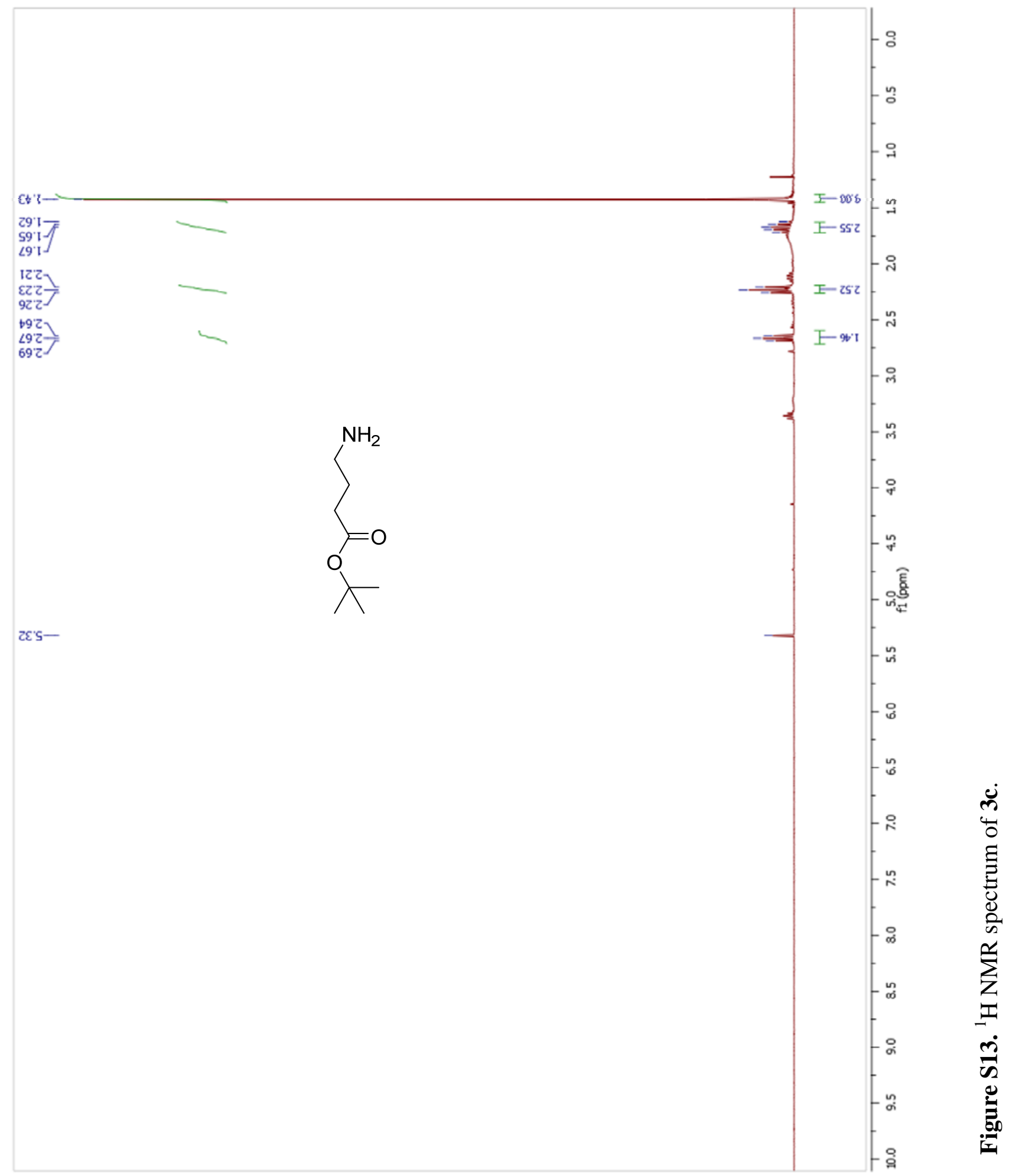




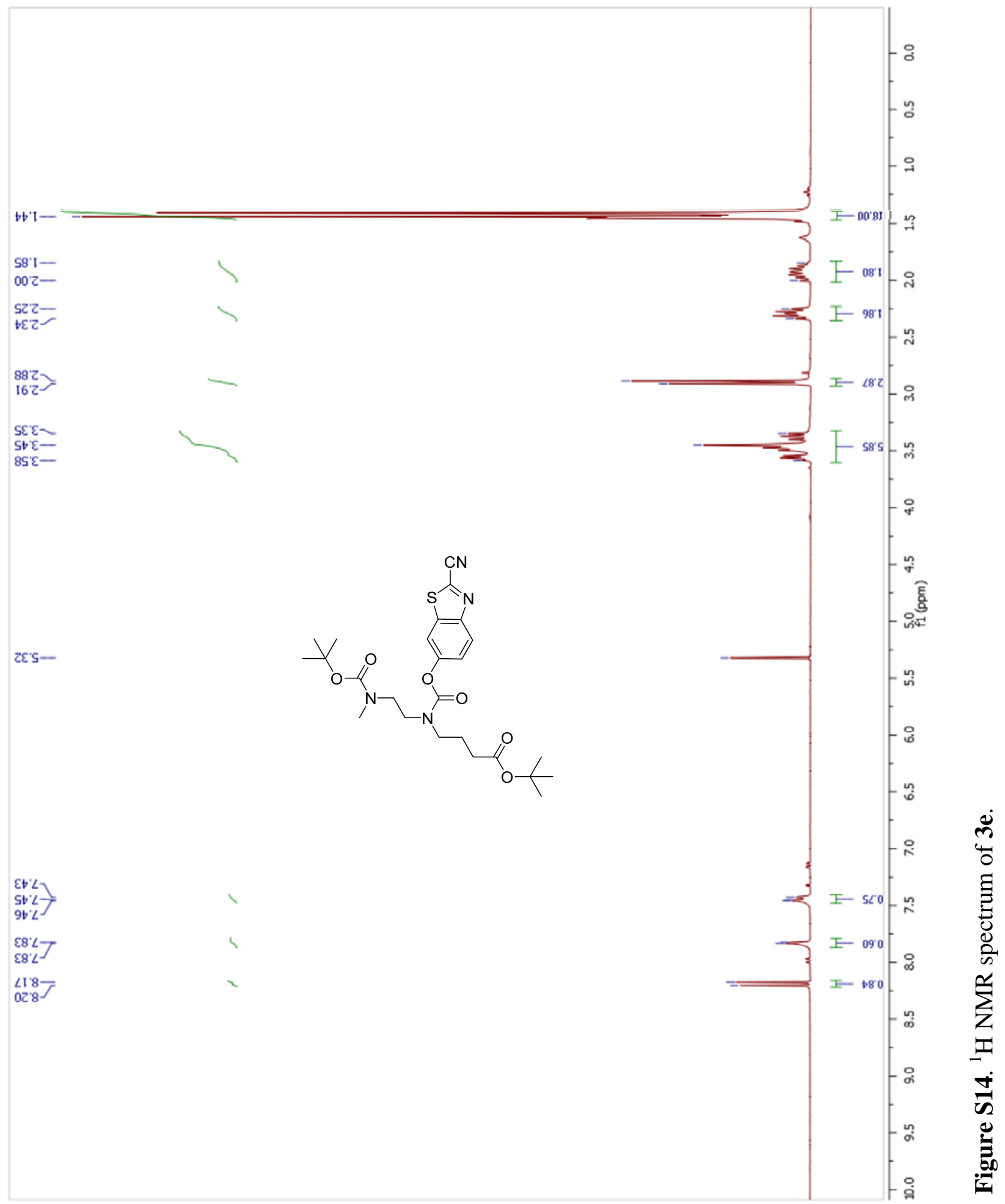




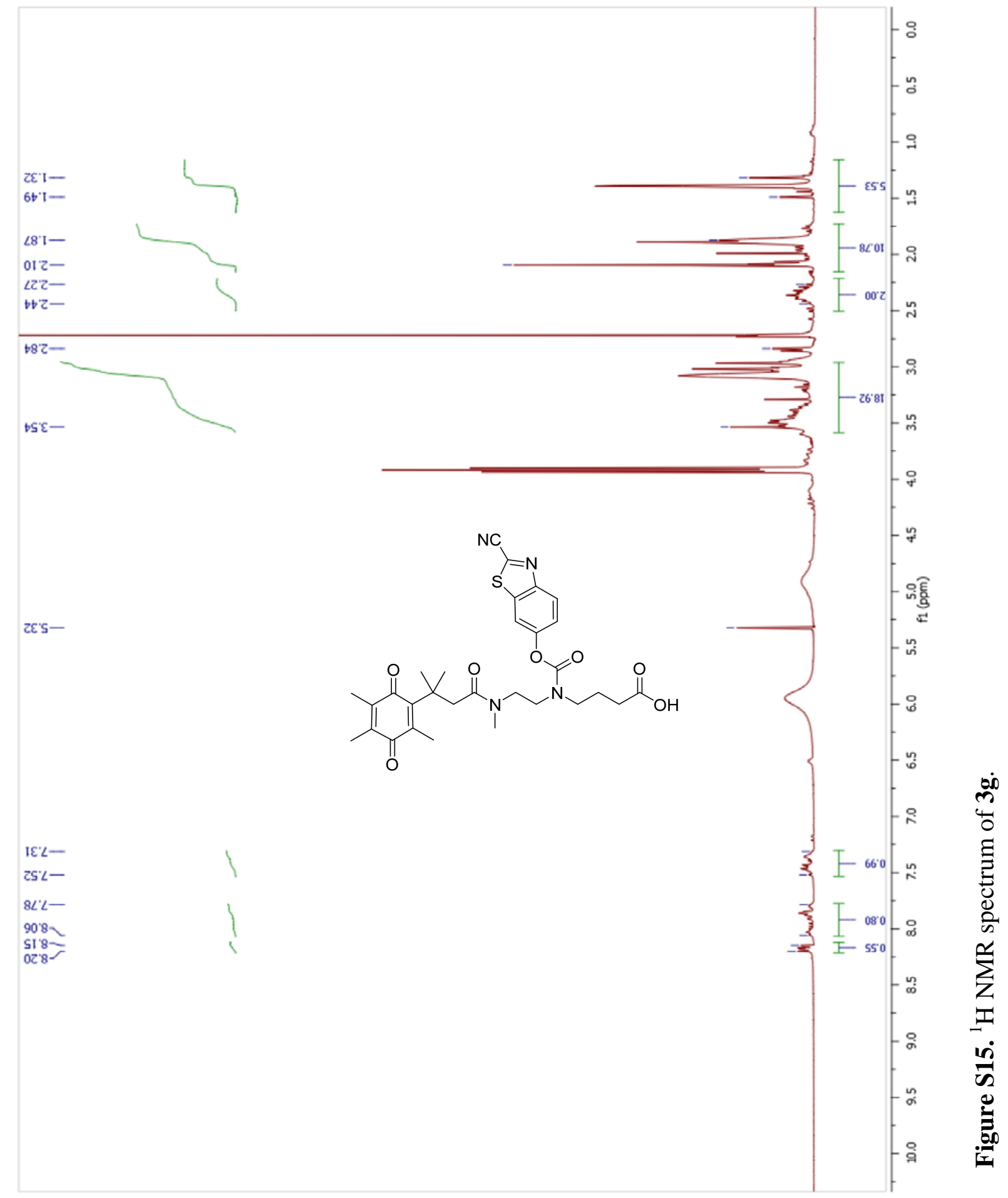




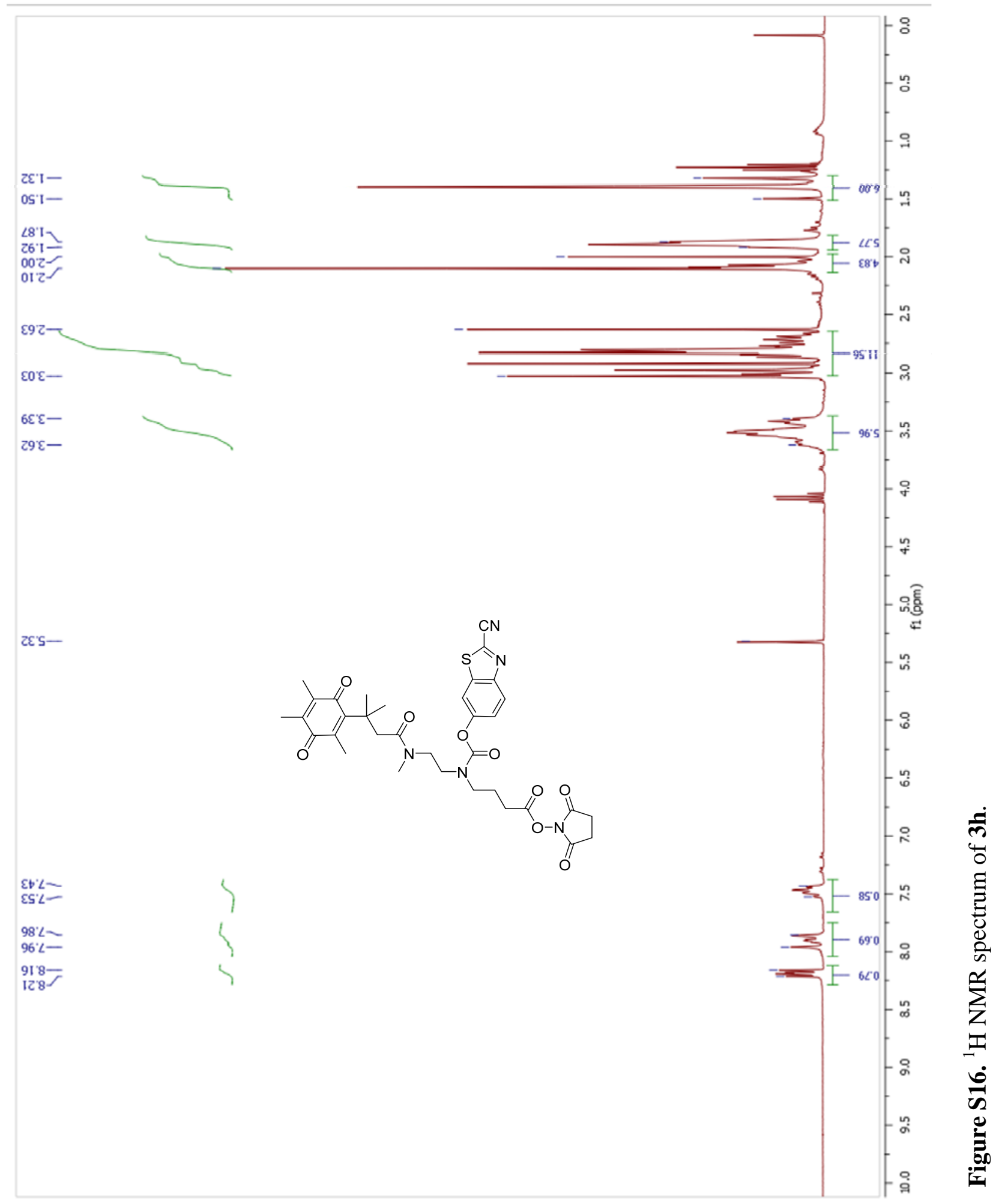




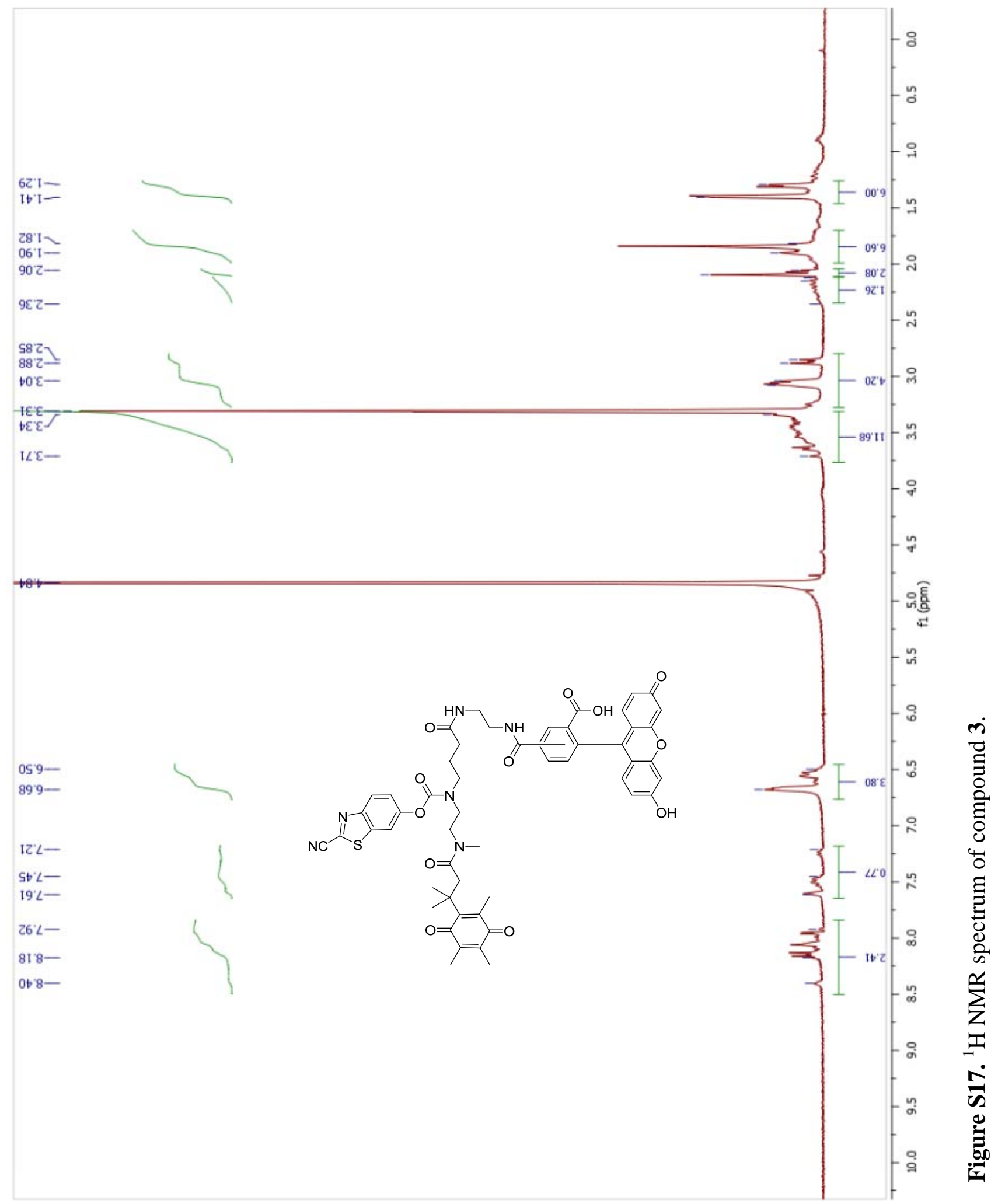




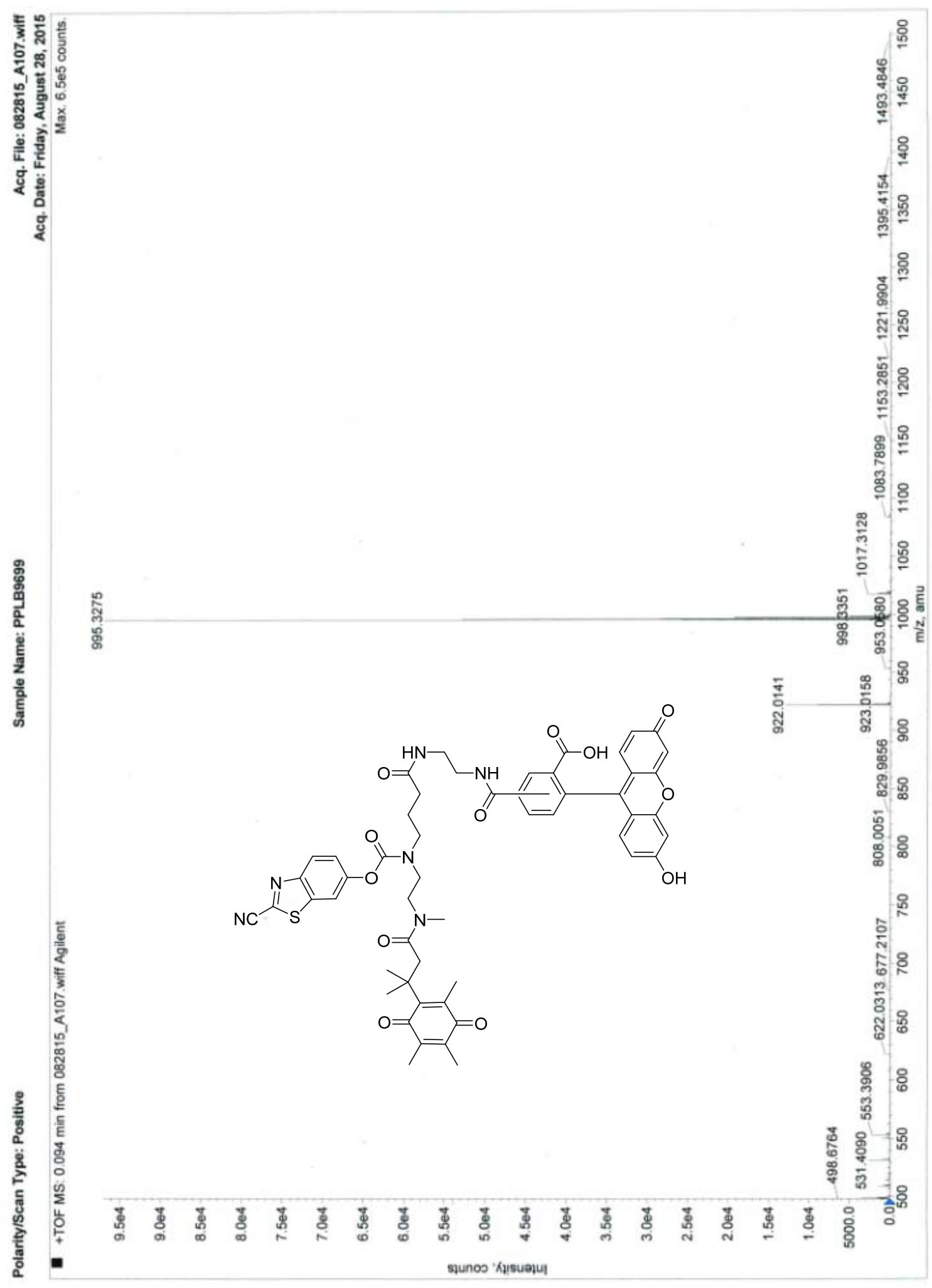

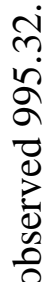

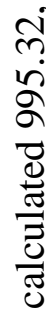

(ิ)

0

䜦

焉

i

。

్ㅡㅇ

4

全

苞 


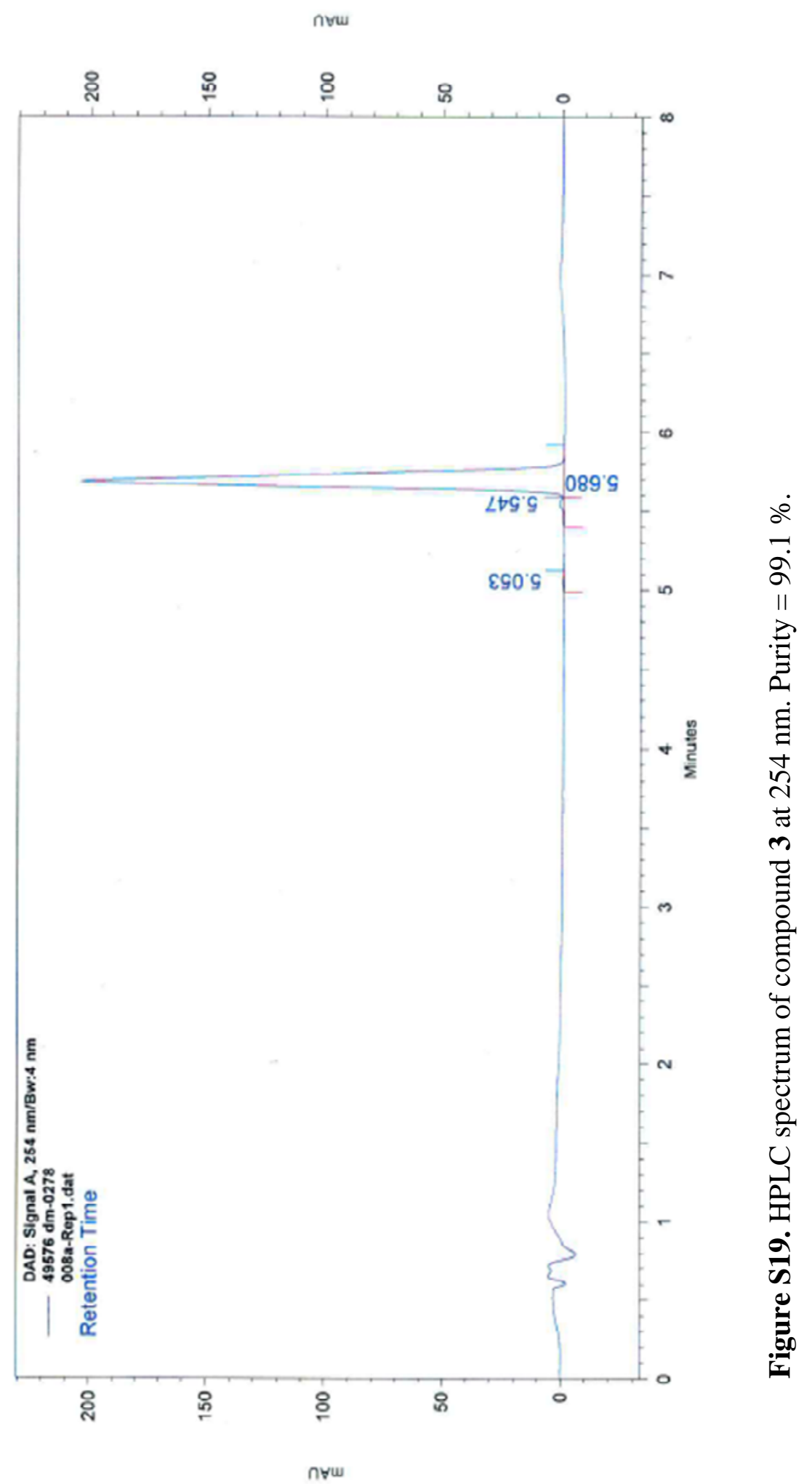




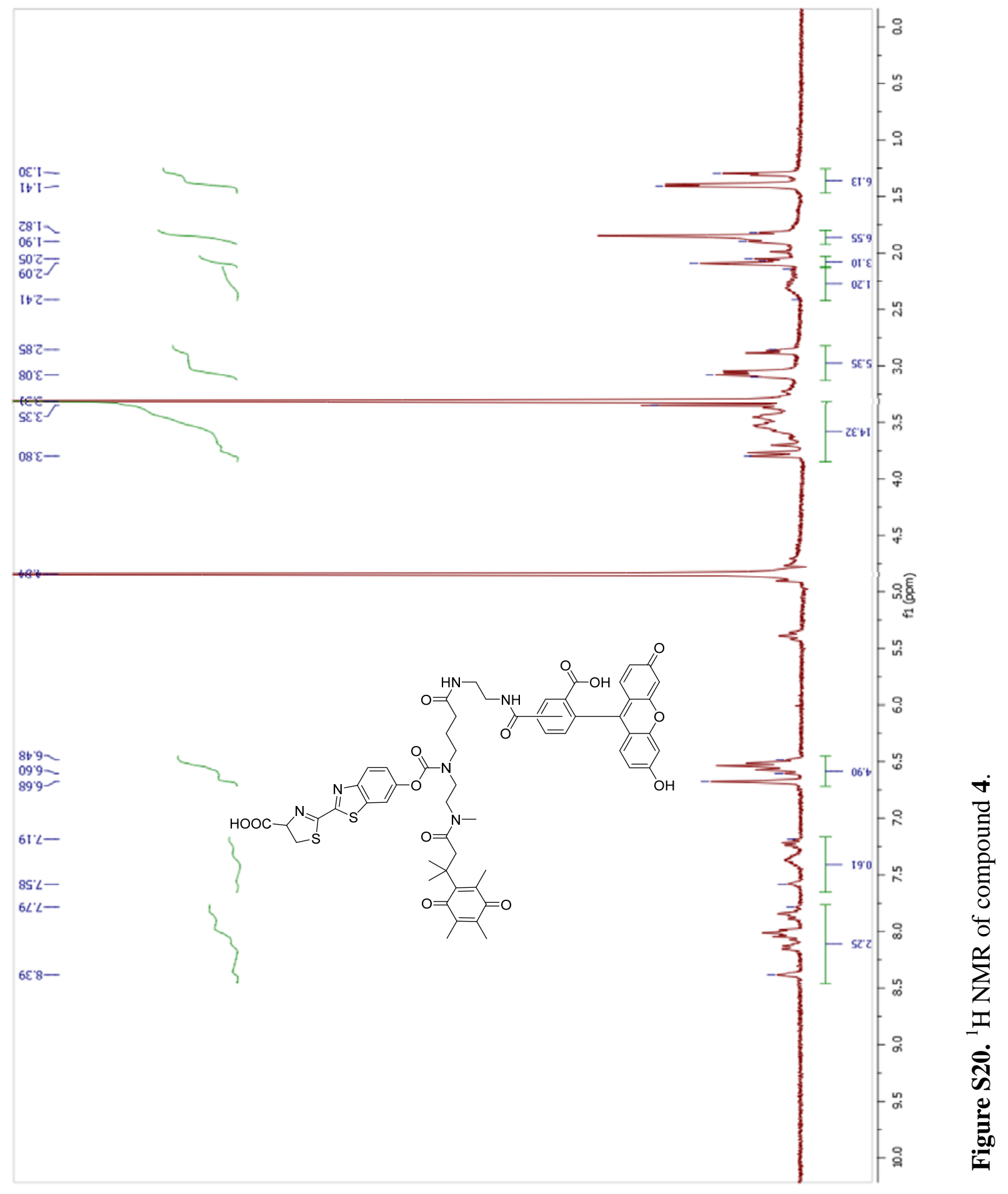




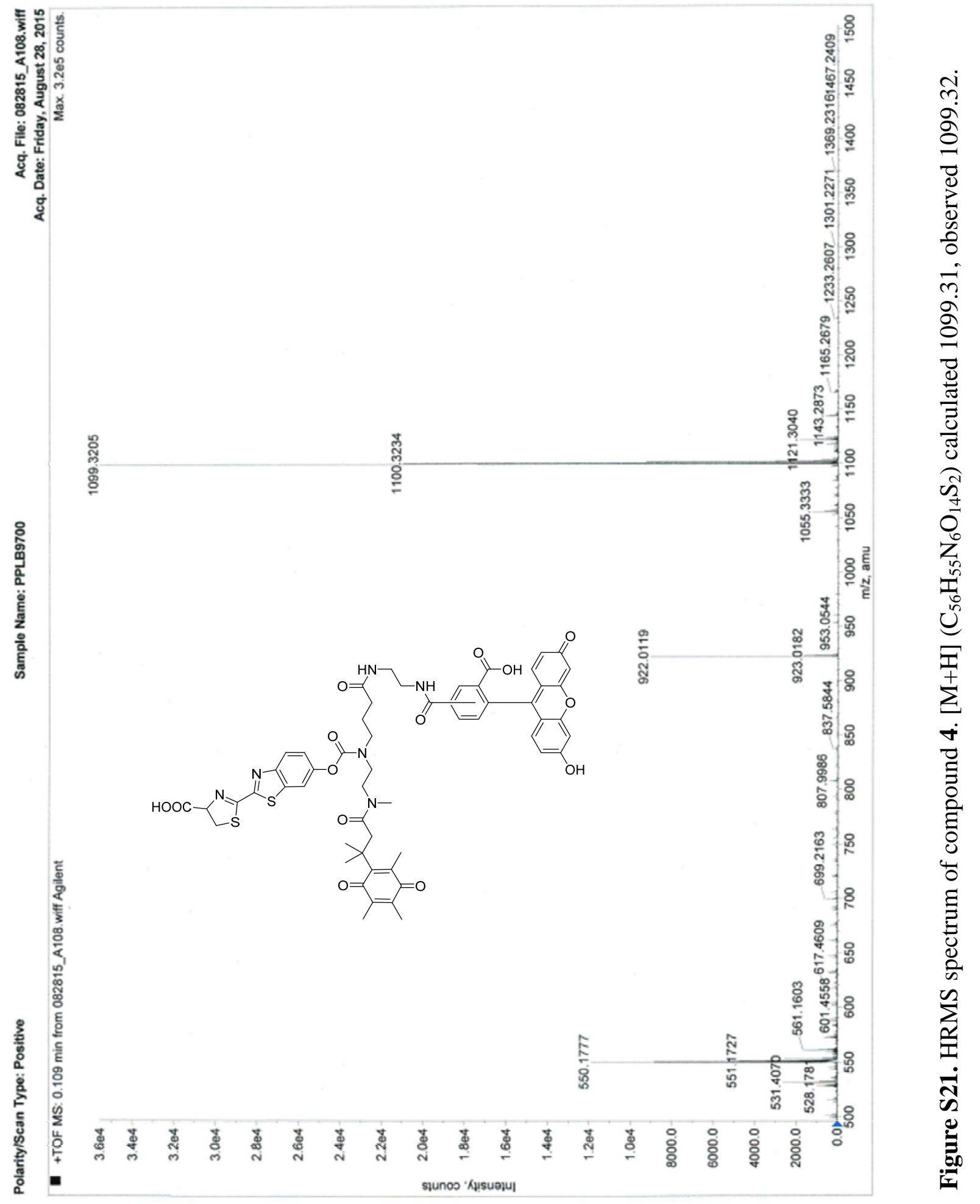




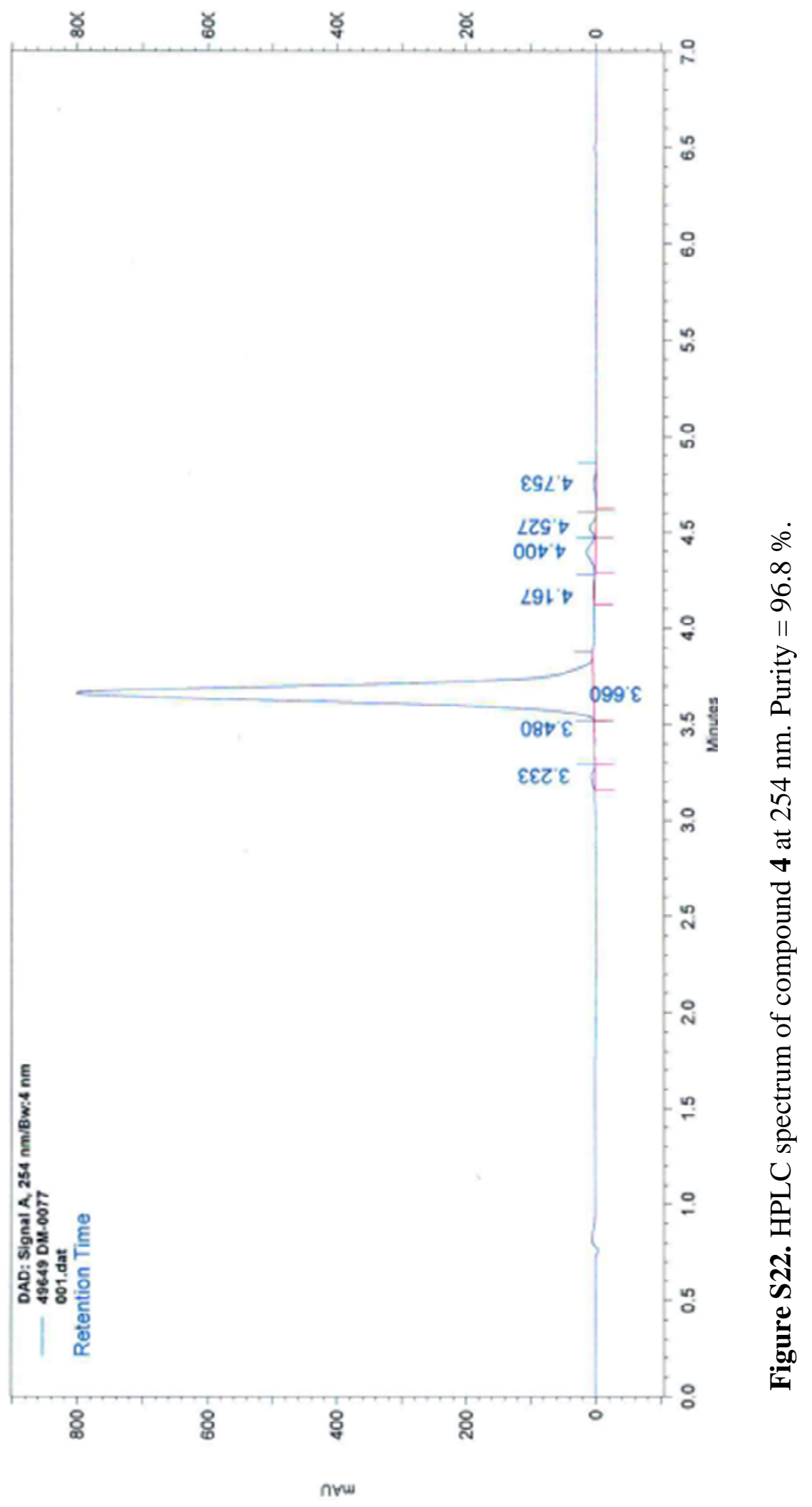




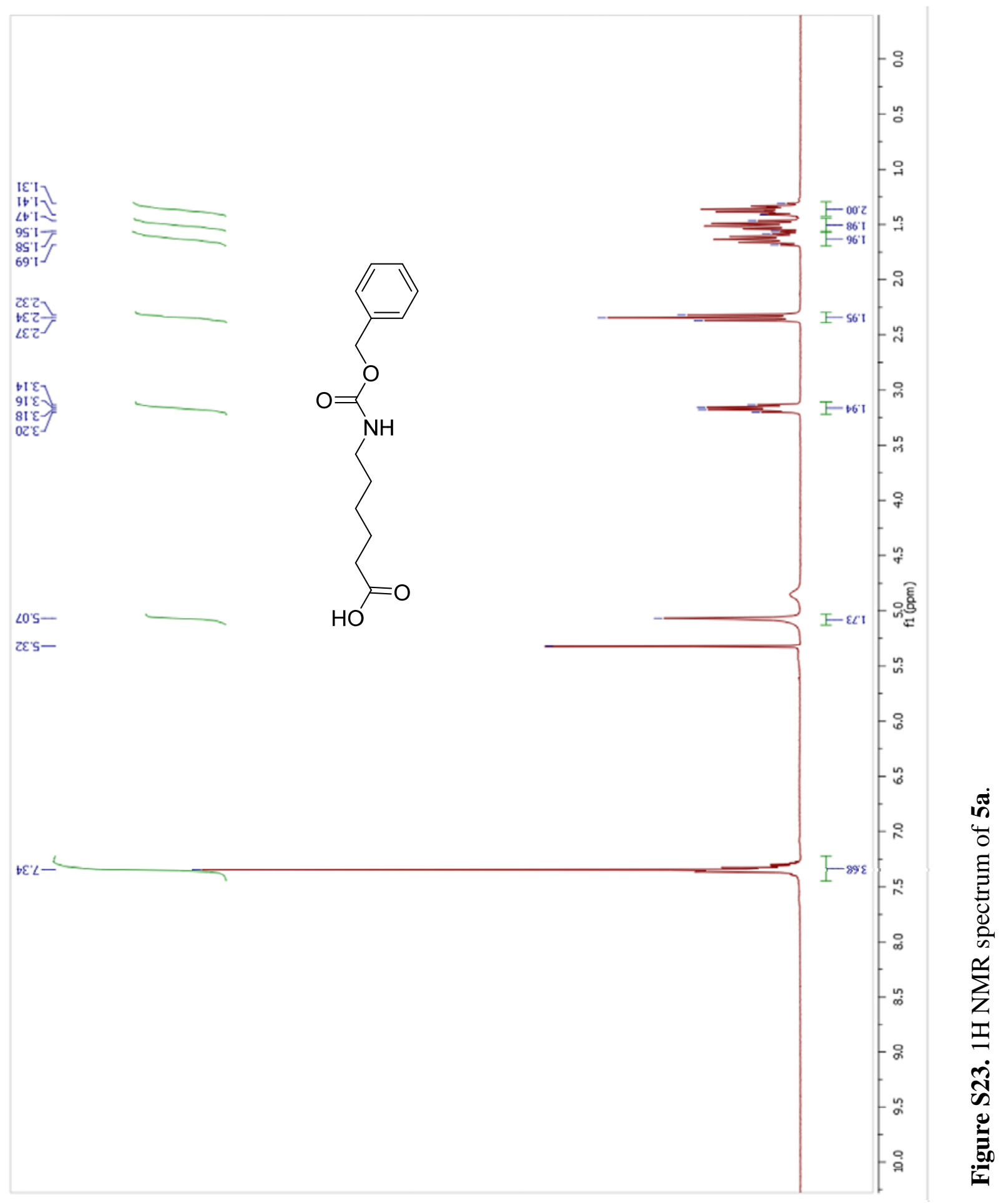




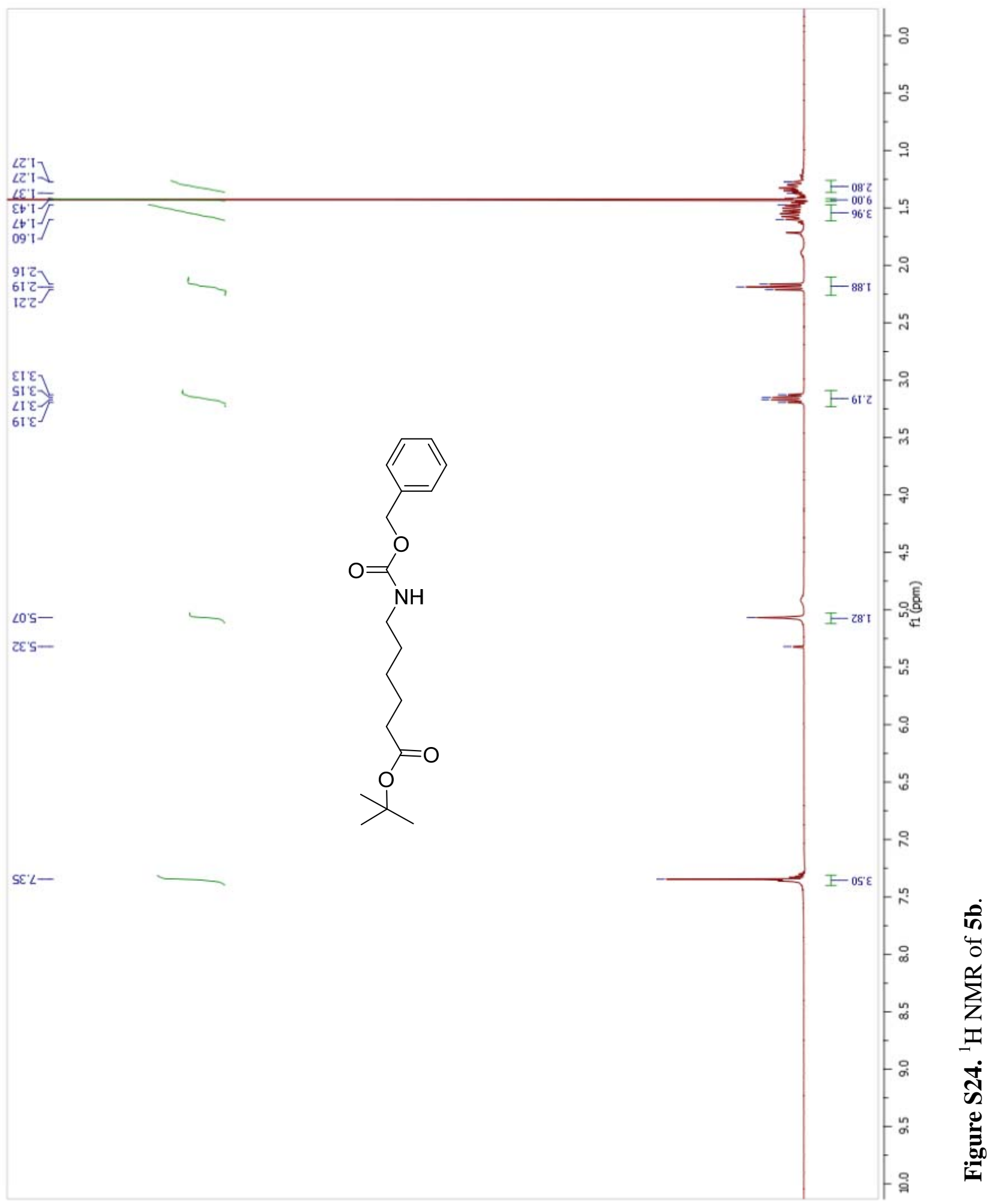




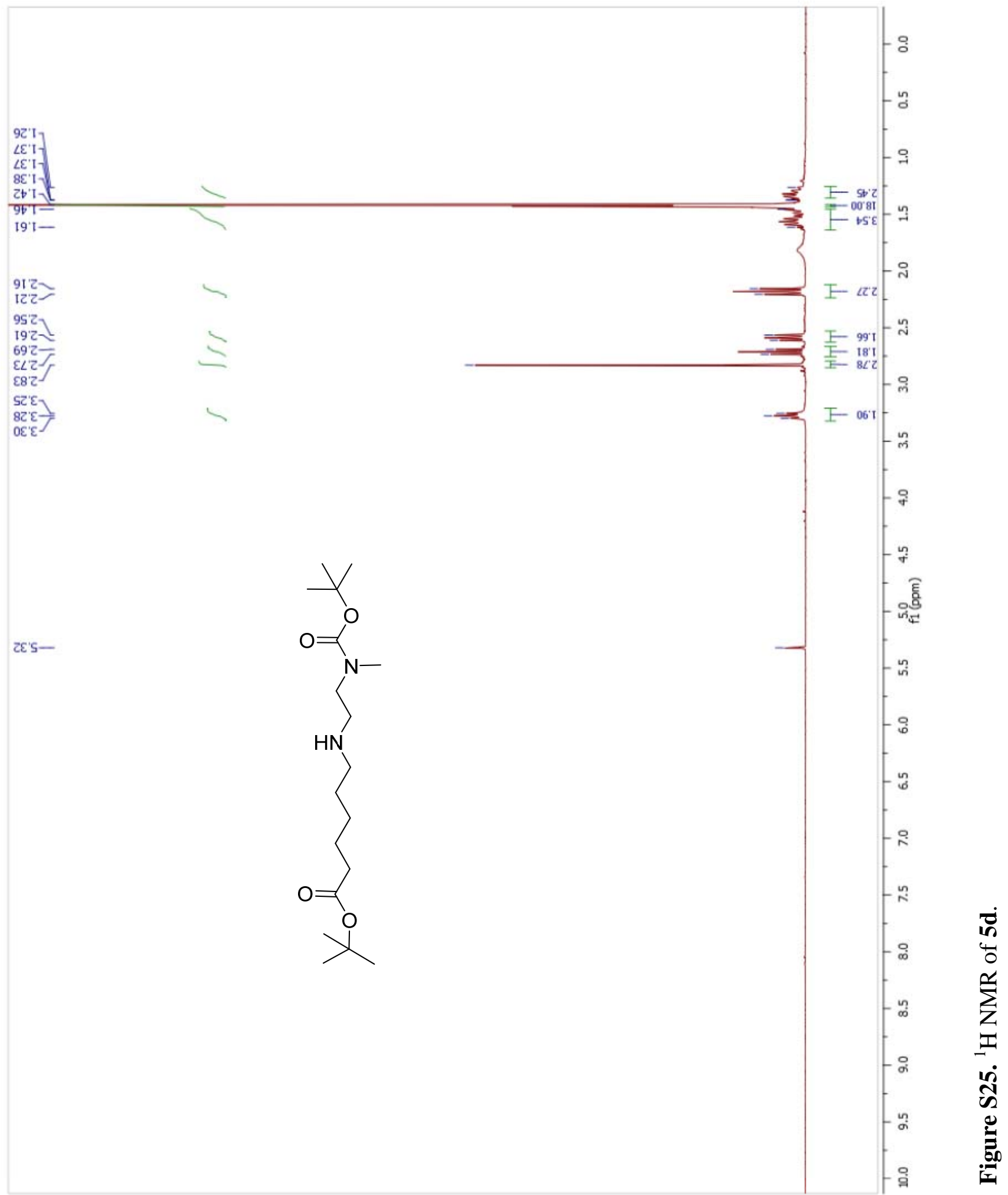




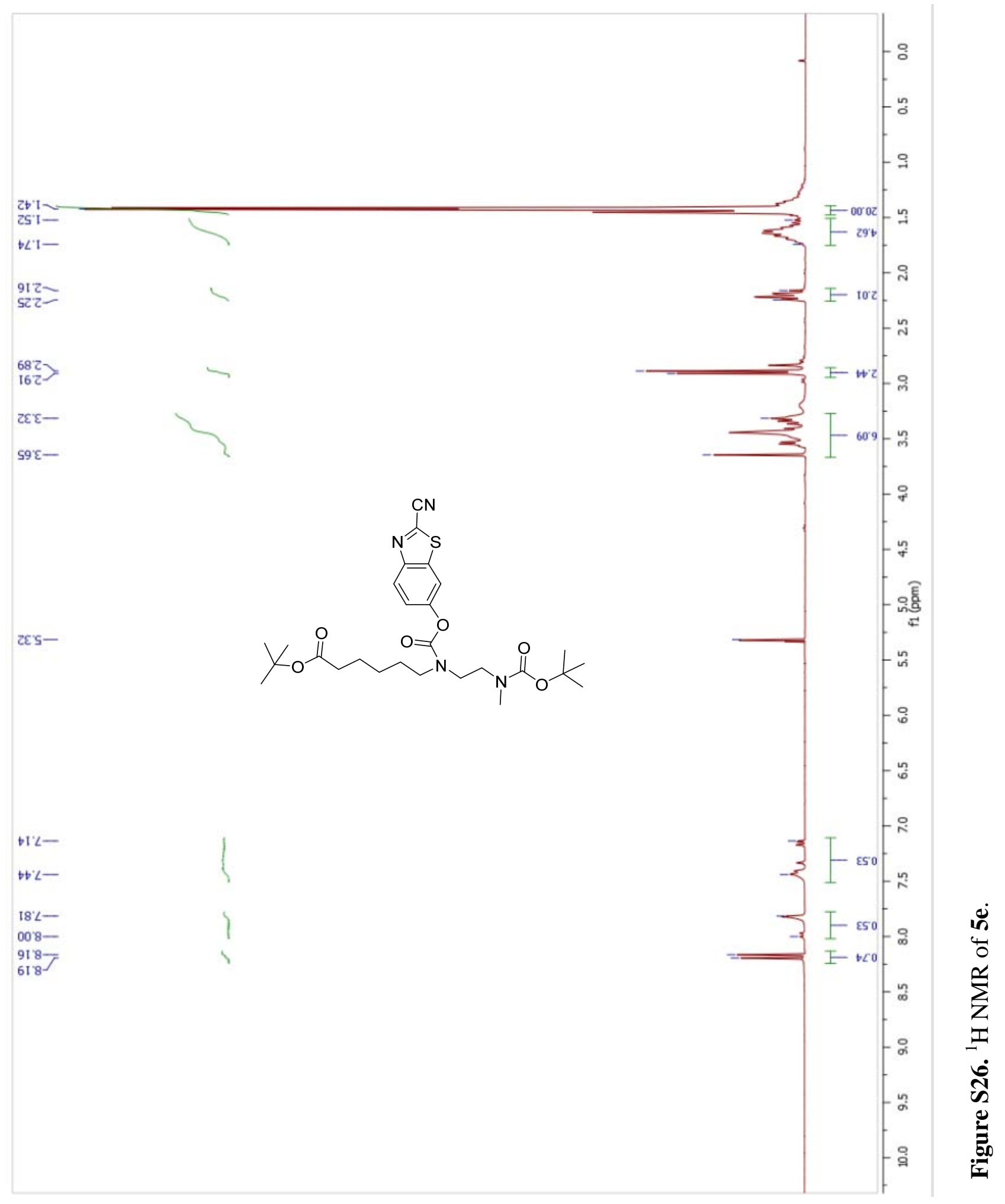




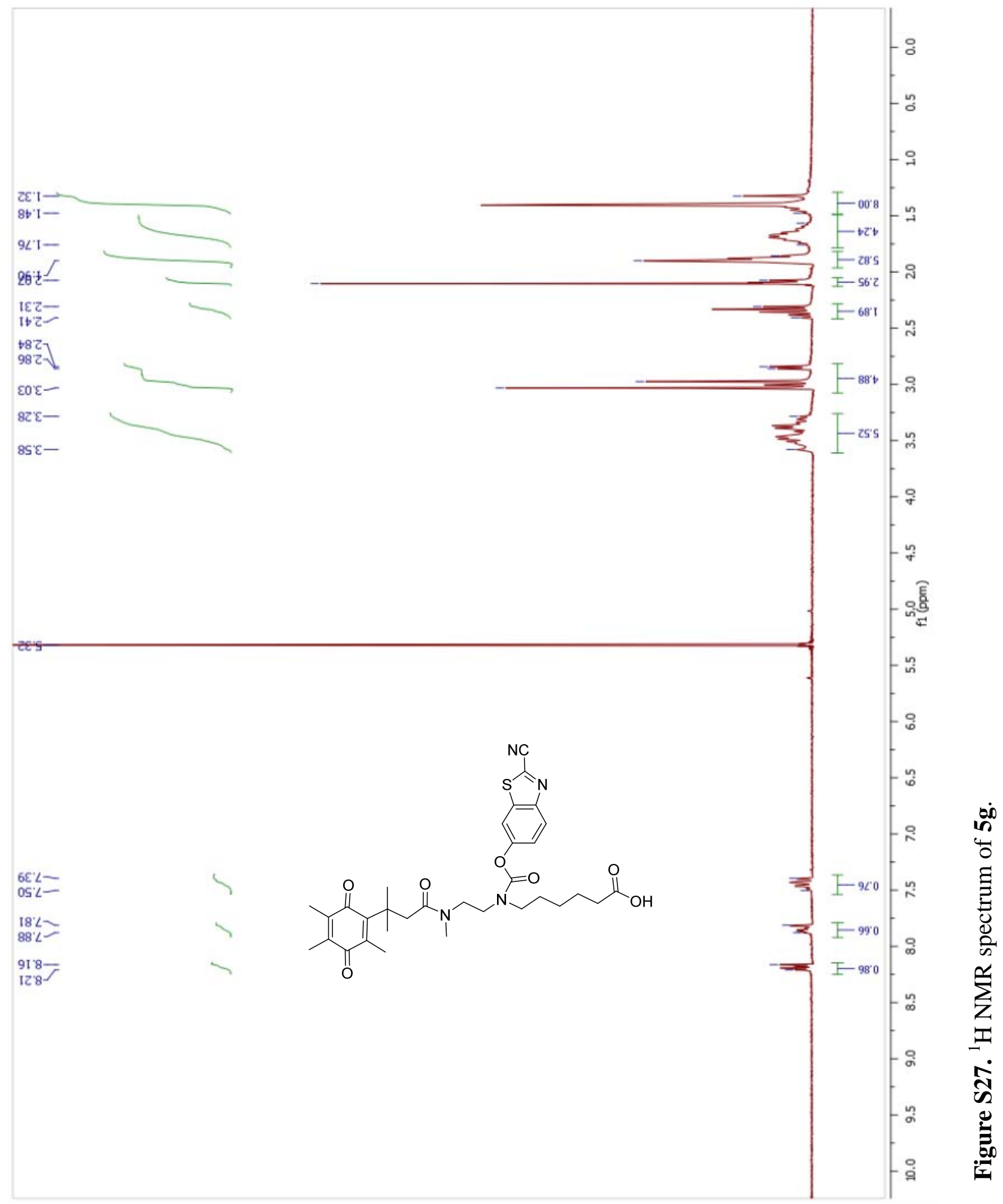




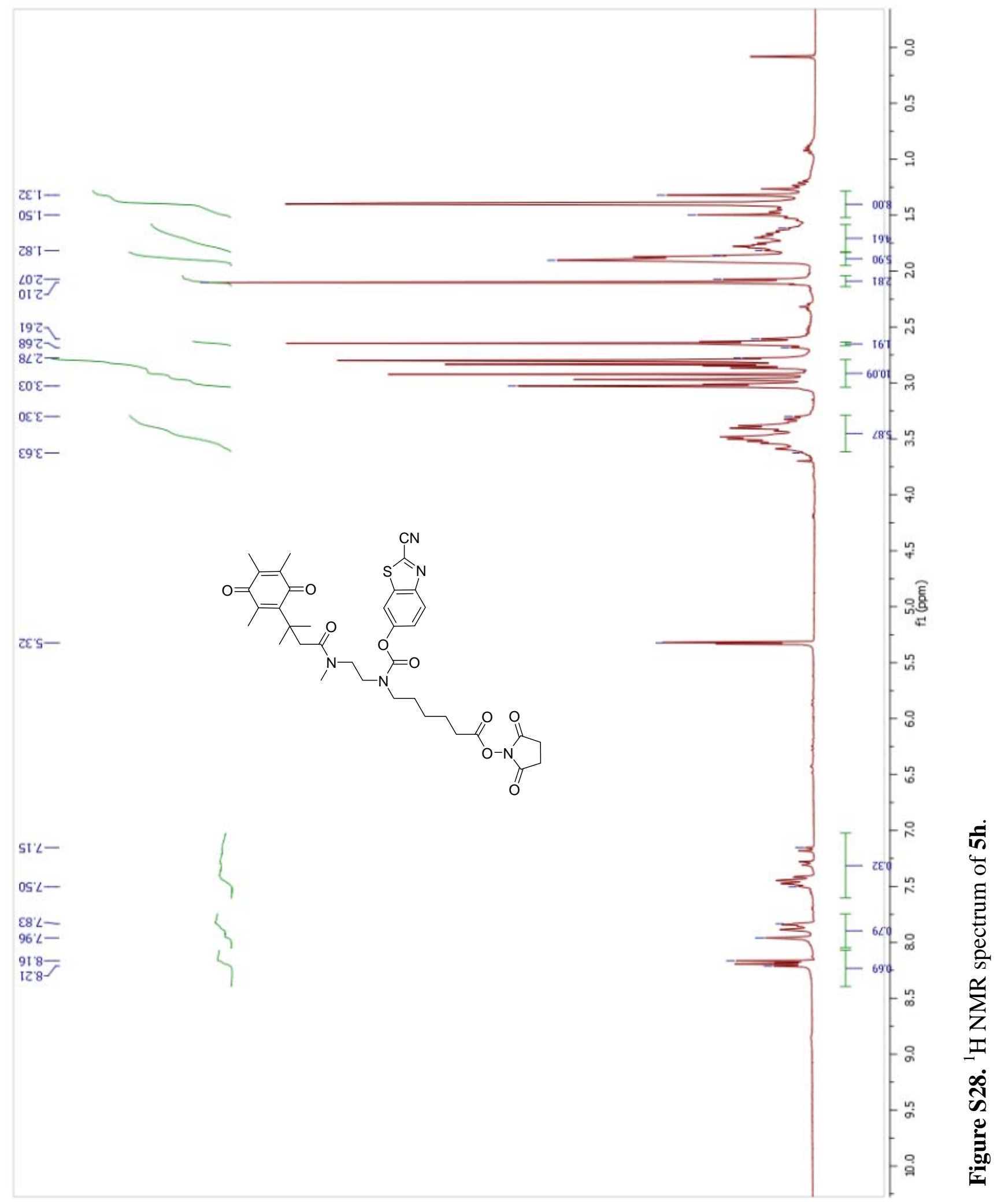




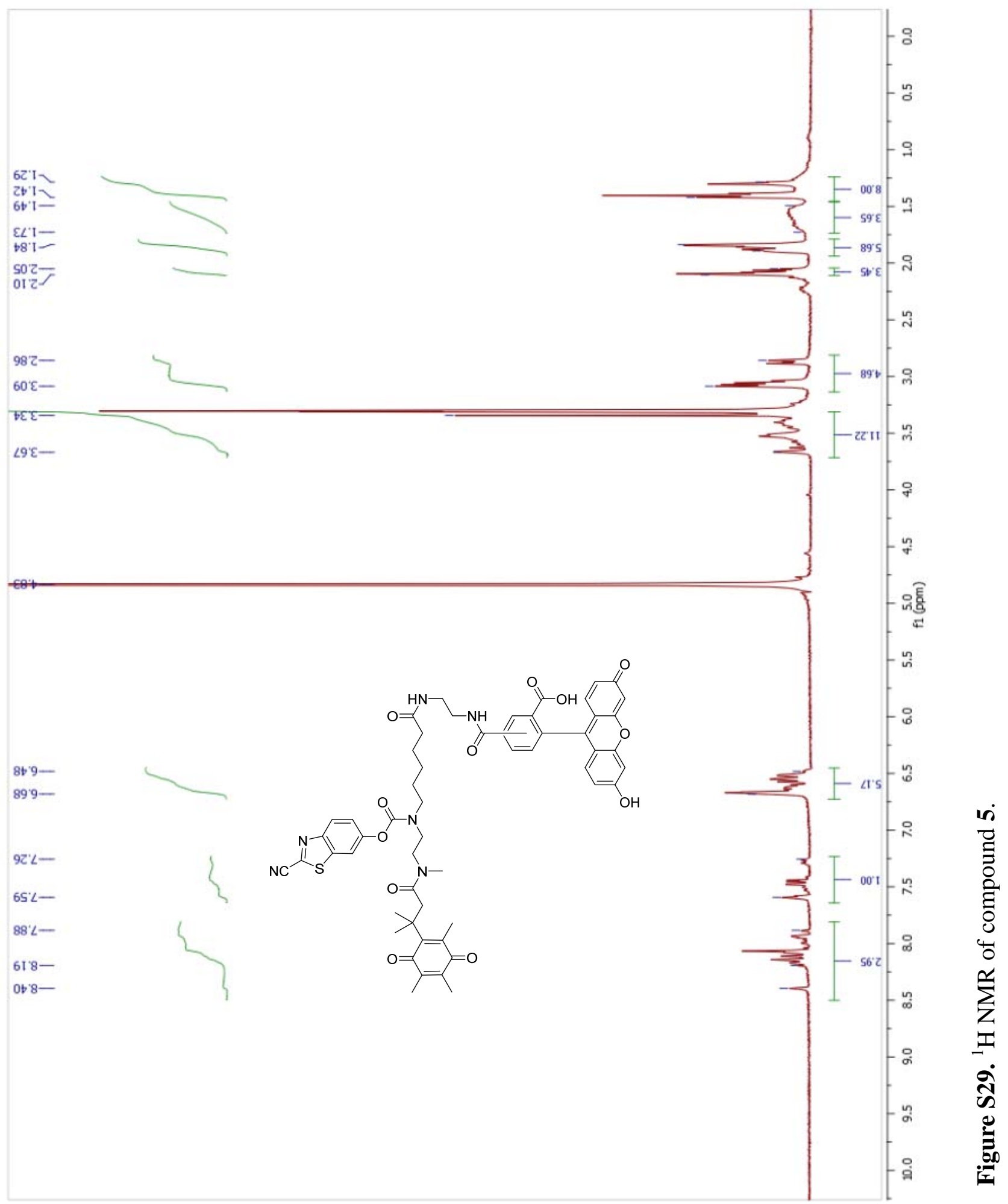



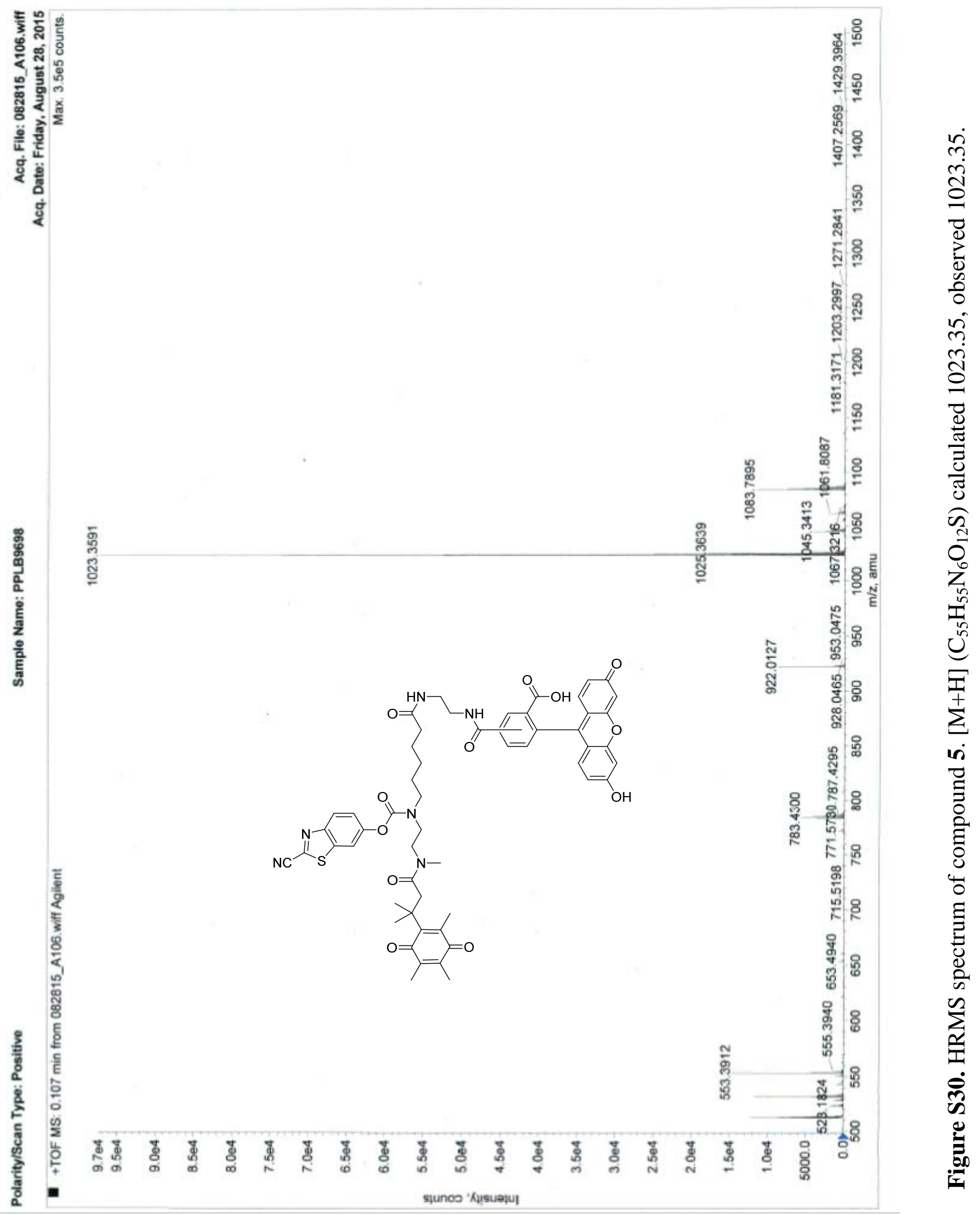


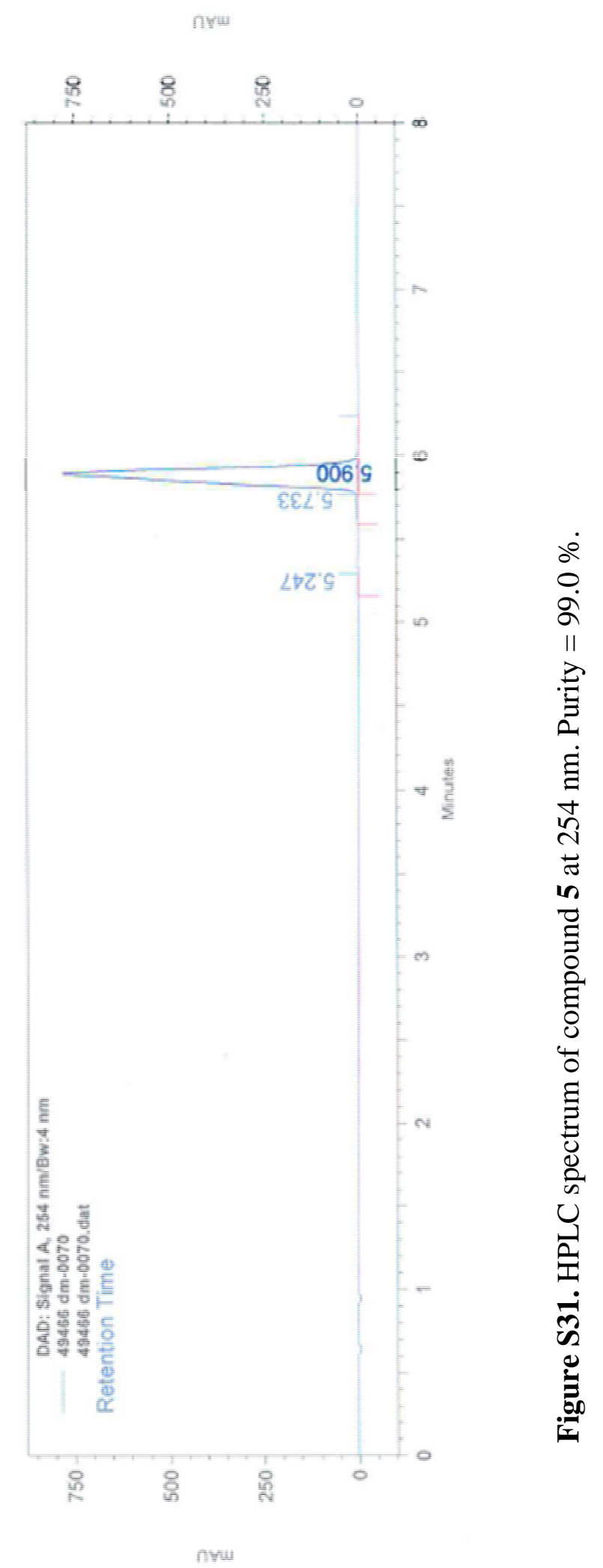




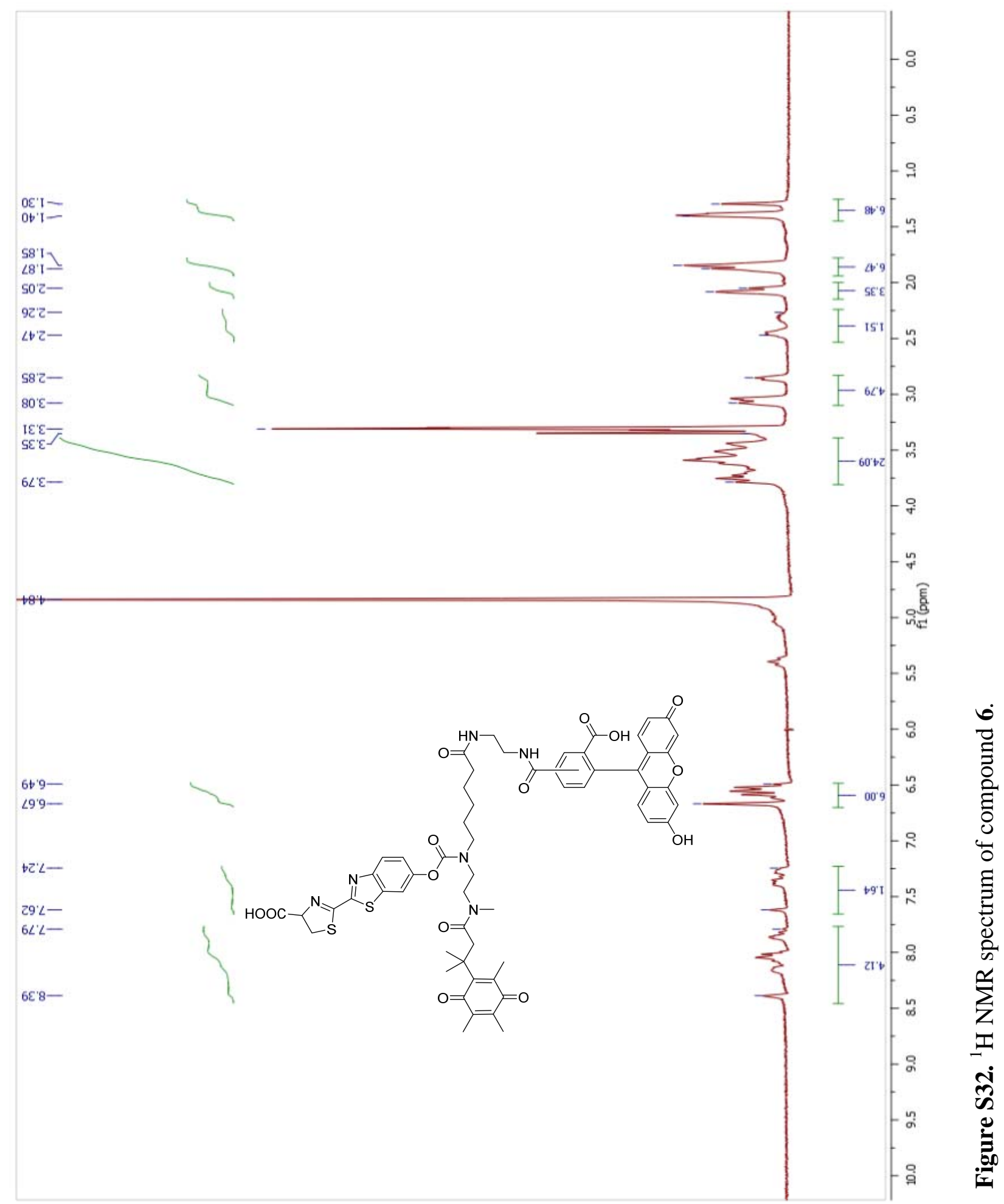




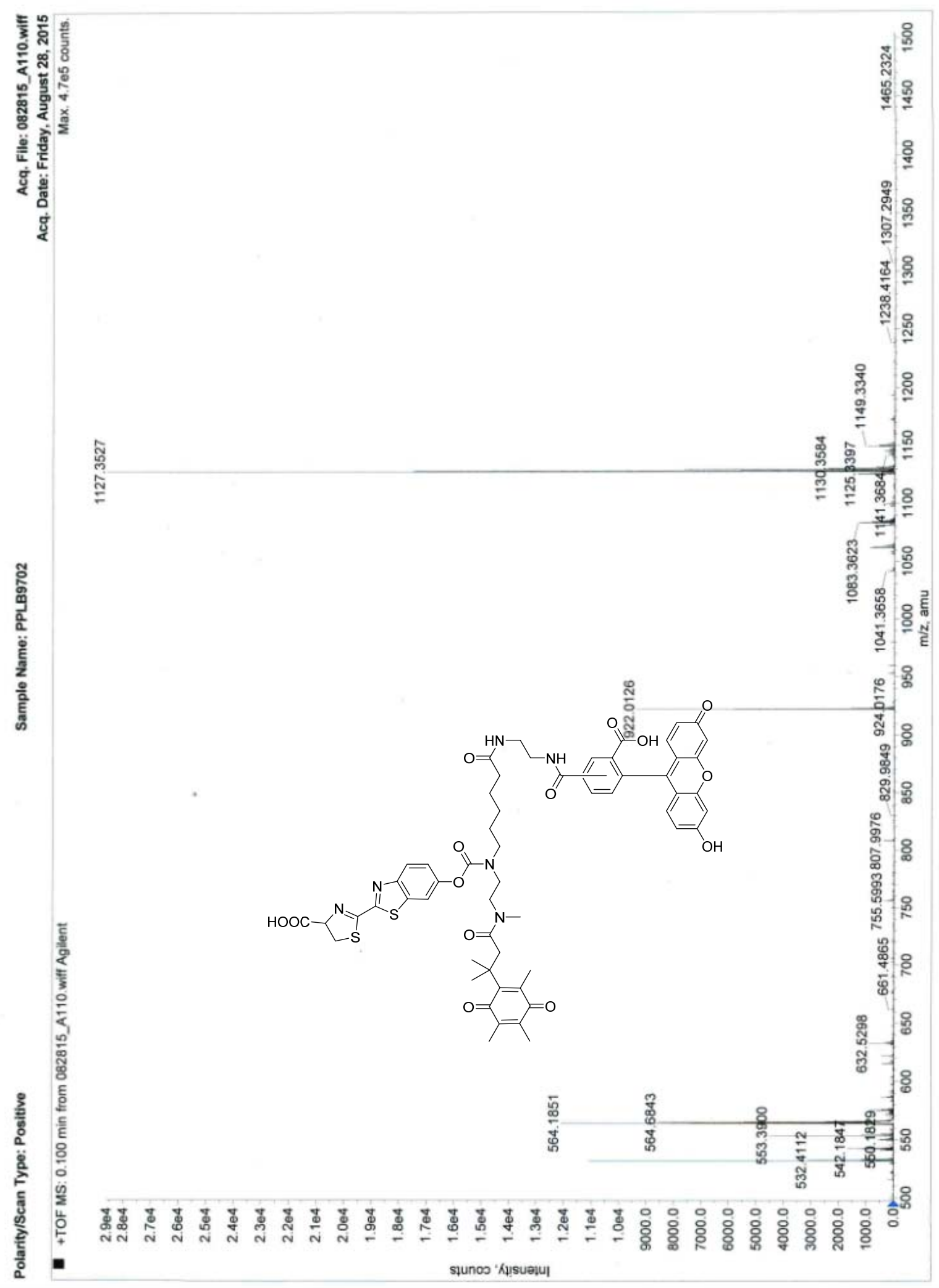

ن 


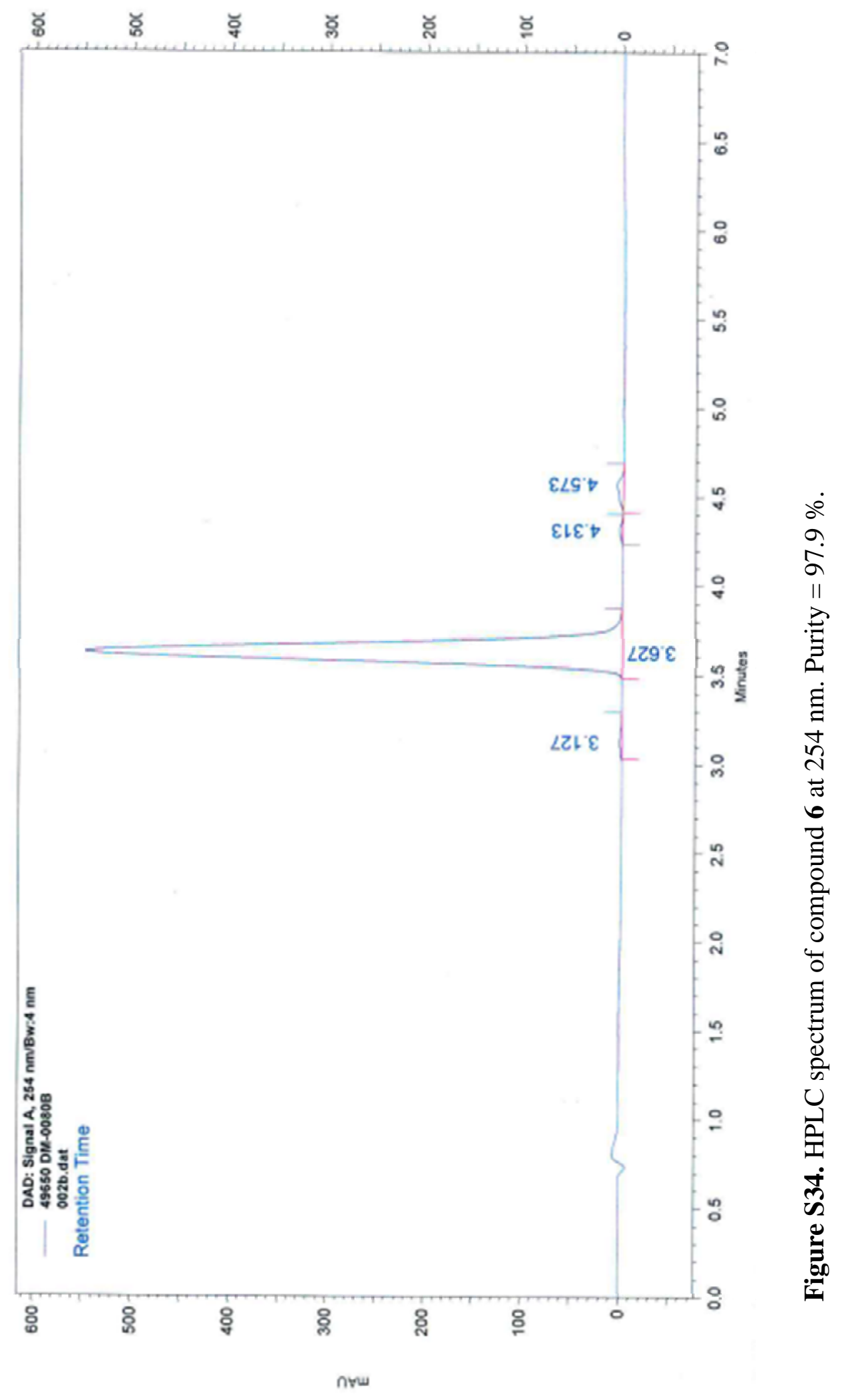




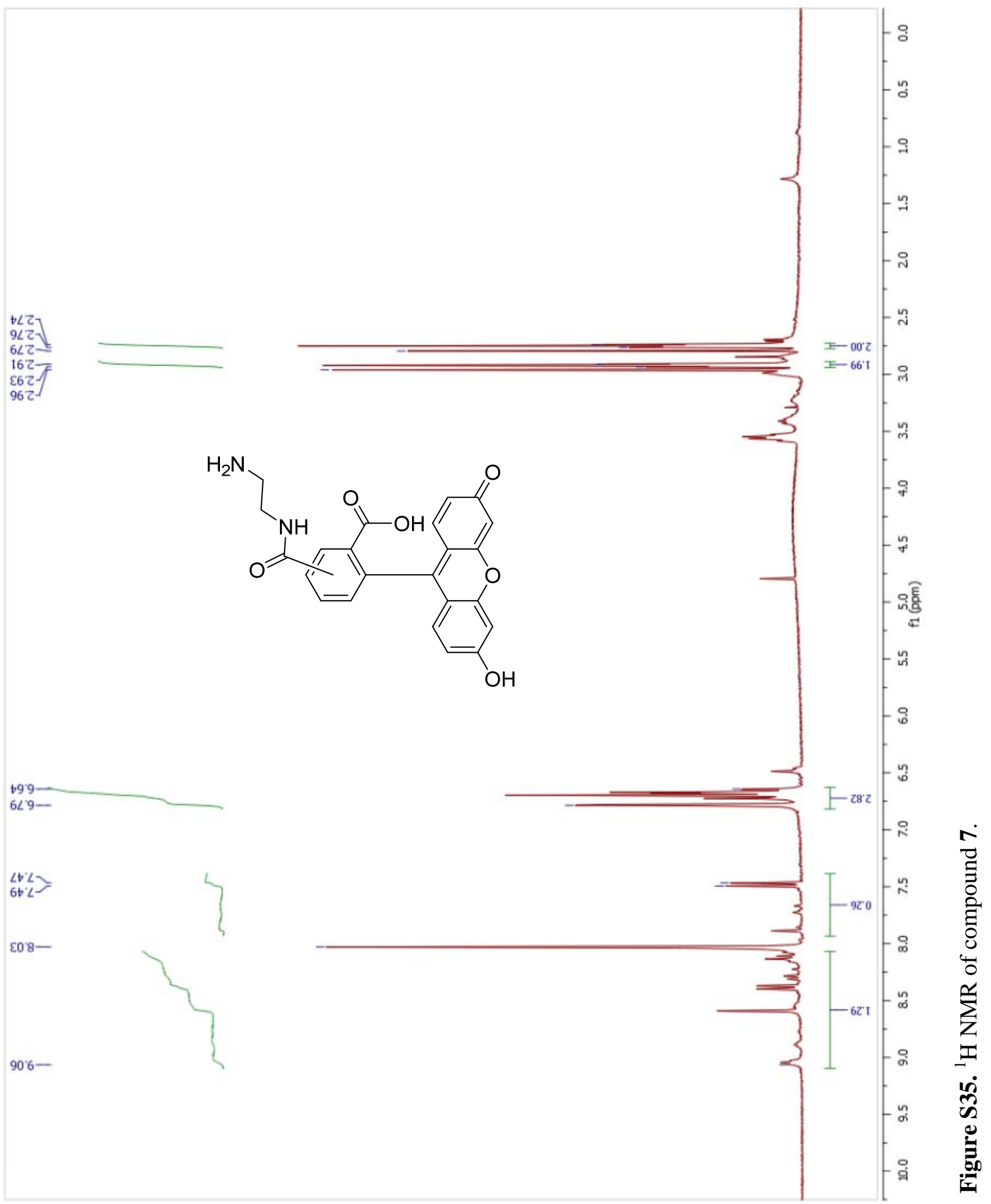

